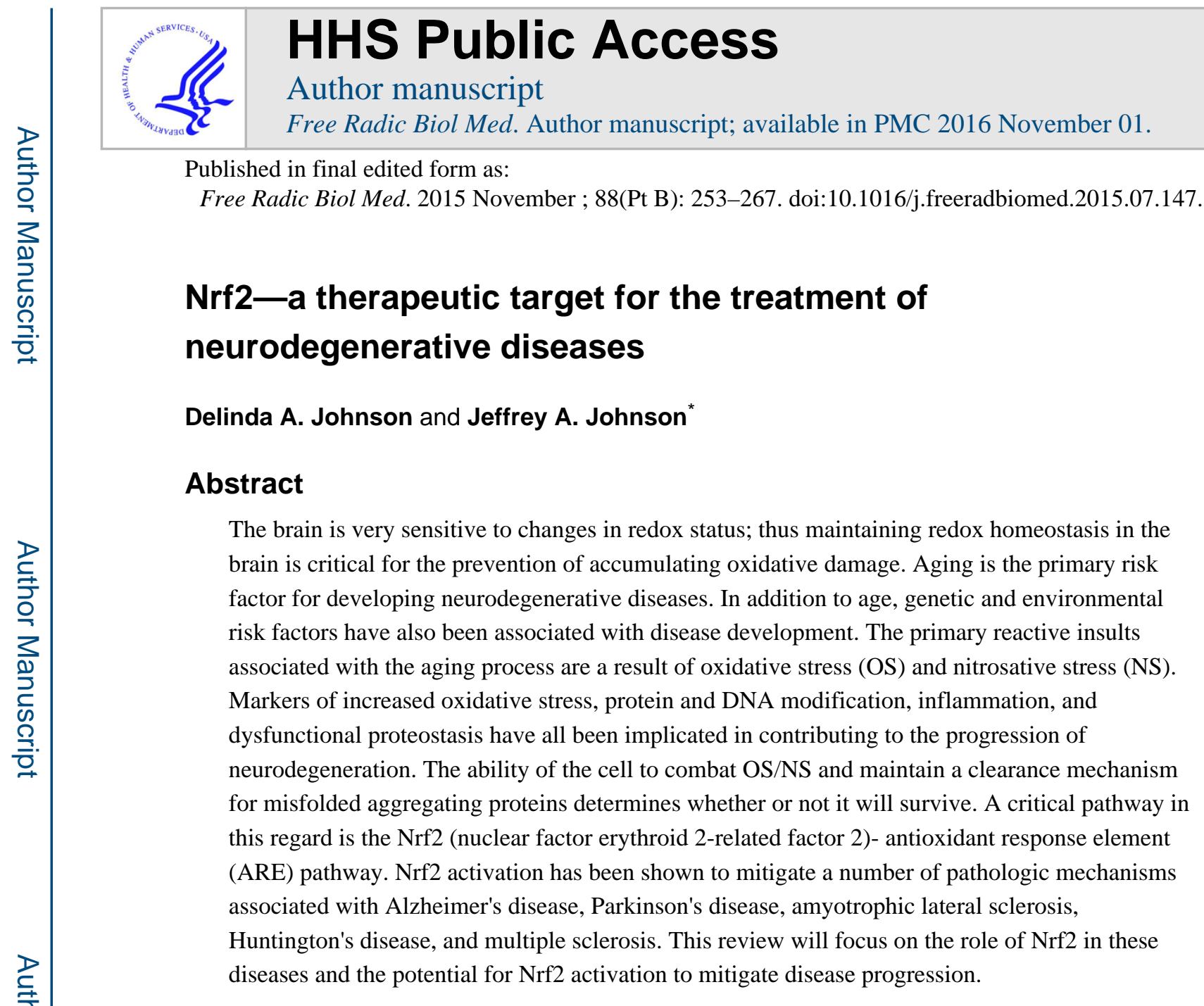

\title{
Introduction
}

\section{OS/NS in neurodegenerative diseases}

The brain is very sensitive to changes in redox status; thus maintaining redox homeostasis in the brain is critical for the prevention of accumulating oxidative damage. Aging is the primary risk factor for developing neurodegenerative diseases. In addition to age, genetic and environmental risk factors have also been associated with disease development. The primary reactive insults associated with the aging process are a result of oxidative stress (OS) and nitrosative stress (NS). OS/NS are produced endogenously via enzymatic and spontaneous reactions through a variety of sources and normal physiological functions $[1, \mathrm{p}$. 26; 2]. Downstream markers of OS/NS have been identified clearly in all neurodegenerative diseases. Signs of lipid peroxidation, such as aldehydes including 4-hydroxynonenol (4HNE), are increased in Parkinson's disease (PD) [3-5], Alzheimer's disease (AD) [6-8], and amyotrophic lateral sclerosis (ALS) $[9,10]$. There is also a correlation between the affected

\footnotetext{
*Corresponding author. jajohnson@pharmacy.wisc.edu..

Publisher's Disclaimer: This is a PDF file of an unedited manuscript that has been accepted for publication. As a service to our customers we are providing this early version of the manuscript. The manuscript will undergo copyediting, typesetting, and review of the resulting galley proof before it is published in its final citable form. Please note that during the production process errors may be discovered which could affect the content, and all legal disclaimers that apply to the journal pertain.
} 
brain regions and 4-HNE adducted proteins [11-13]. Another major marker of OS production is protein carbonyls, representing protein oxidation. Carbonyls are present in the substantia nigra (SN) in PD [14, 15], AD [16], and ALS [17] and in affected brain regions in other diseases [18-21]. Oxidative damage to DNA/RNA has been evaluated by measuring 8hydroxy-2-deoxyguanosine (8-OHDG) and is increased in central and peripheral nervous systems of patients with neurodegenerative diseases [22-30]. Post-translational modification proteins modify protein structure and function. Protein structure and function can be altered by phosphorylation, nitration, ubiquitination, and glycosylation. Such modifications have been observed in alpha-synuclein (SYN) in patients with synucleinopathies including PD and dementia with Lewy bodies (DLB) [31-33]. Nitration and phosphorylation of tau protein has been found in the hippocampus and neocortex of patients with $\mathrm{AD}$ and other tau pathologies [34, 35]. Nitrotyrosine-modified proteins are elevated eightfold in the hippocampus and neocortex of AD brains [36, 37]. These region-specific protein modifications correlate with areas of increased OS/NS in the brain. Furthermore, such modifications are thought to contribute to protein misfolding and subsequent aggregate/ inclusion formation. Because most neurodegenerative diseases have characteristic misfolded protein aggregates, such as SYN in PD, beta-amyloid (A $\beta$ ) plaques and hyperphosphorylated tau neurofibrillary tangles (NFTs) in $\mathrm{AD}$, huntingtin (Htt) in Huntington's disease (HD), and superoxide dismutase 1 (SOD1) in ALS, protein aggregation and regulation of misfolded protein clearance by the proteasome and autophagy appear to be vital to pathogenesis.

\section{Keap1-Nrf2-ARE pathway}

One of the primary endogenous sources of OS is the mitochondrial electron transport chain. Increased mitochondrial dysfunction associated with neurodegenerative diseases leads to increased OS generation and reduction in the production of ATP. In addition and associated with neuroinflammation, the enzymes of the NADPH oxidase system generate superoxide anions. The combination of superoxide anion with nitric oxide, produced by nitric oxide synthase, generates the highly reactive NS peroxynitrite. Combating OS/NS is dependent upon the cell's ability to maintain cellular redox homeostasis. A critical pathway in this regard is the Nrf2 (nuclear factor erythroid 2-related factor 2)- antioxidant response element (ARE) pathway. The ARE is an enhancer element having the consensus sequence RTGACnnnGC, which is located in the 5' flanking region of many phase II detoxifying and antioxidant genes [38, 39]. Nrf2 is a cytoplasmic protein sequestered by the actin-bound protein Keap1 (Kelch ECH associating protein) [40, 41]. Keap1, a Cul3-based E3 ligase, polyubiquitinates $\mathrm{Nrf} 2$, targeting it for subsequent proteasomal degradation [42, 43]. Oxidative stress or exposure to electrophilic agents that react with Keap1 stabilize Nrf2, leading to increased Nrf2 protein levels and nuclear accumulation of Nrf2. Once in the nucleus, Nrf2 dimerizes with small Maf proteins and binds to the ARE, transcriptionally driving expression of several detoxifying and antioxidant genes [44, 45].

Nrf2 contains six well-conserved Nrf2-ECH homologous (Neh) domains that support molecular functions. The CNC (cap ' $n$ ' collar) and DNA binding regions are located in the Neh1 domain, as is the Maf dimerization site. Neh4 and Neh5 are necessary for recruitment of transcription factors and other canonical proteins required for gene expression [46]. Molecular studies have determined that the Neh2 domain is required for the cytoplasmic 
localization of Nrf2, because deletion of Neh2 leads to continuous nuclear translocation of Nrf2 to the nucleus. Yeast two-hydridization screening using the Neh2 domain from Nrf2 as bait identified Keap1 as an Nrf2 binding protein. Eighty percent of the independently isolated clones screened were Keap1 positive, suggesting specificity of the Keap1-Nrf2 interaction [40]. Keap1 has two canonical domains, the Kelch domain and the bric-a-brac, tramtrack, broad-complex (BTB) domain. The Kelch domain binds actin and thus tethers the Keap1-Nrf2 complex to the cytoskeleton. The BTB domain is important for protein dimerization of Keap1 molecules. There are many cysteine residues in the Keap1 protein that potentially function as sensors of oxidants and electrophiles; humans have 27 and rat and mouse have 25 [44, 47]. The "hinge and latch" model proposes that two Keap1 molecules bind Nrf2 at high- and low-affinity sites located in the Neh2 domain [48]. The hinge domain, EGTE, supports high affinity and the latch domain, DLG, low affinity. When Keap1 senses oxidative or electrophilic stress, the low-affinity domain binding Nrf2 is abolished and proteosomal degradation of Nrf2 is disrupted [49]. In addition to Keap1, Nrf2 turnover can be regulated by GSK3 $\beta / \beta$-TrCP- and Hrd1-dependent mechanisms in different pathological states [50, 51]. GSK3 $\beta$ phosphorylates the Neh6 domain of Nrf2.

Phosphorylation of Neh6 domain facilitates binding of the $\beta$-TrCP/Cul1 E3 ligase complex to Nrf2. Nrf2 is then ubiquitinated and degraded through $\beta$-TrCP-mediated proteasomal degradation. Hrd1 is another E3 ubiquitin ligase that resides in the endoplasmic reticulum membrane. Hrd1 directly interacts with Nrf2 at the Neh4-5 domains by binding to the cytoplasmic C-terminal region of Hrd1, leading to Nrf2 ubiquitination and degradation.

In addition, there are endogenous proteins that have been shown to interact with Keap1 and activate the Nrf2 pathway. An initial screen using Nrf2-dependent ARE-luciferase activity identified seven activating proteins: sequestosome 1 (SQSTM1 or p62), D-site of albumin promoter binding protein (DBP), dipeptidylpeptidase 3 (DPP3), BCL2-like the 1 (BCL2L1; longer isoform, Bcl- $\mathrm{x}_{\mathrm{L}}$ ), the kinesin family member 26B (KIF26B), cAMP-responsive element binding protein-regulated transcription coactivator 1 (TORC1), myeloid cell leukemia sequence 1 (MCL1; longer isoform, Mcl-11), and the splicing factor arginine/ serine-rich 10 (SFRS10) [52]. Subsequently, both SQSTM1 and DPP3 were shown to interact with Keap1 $[53,54]$. The Wilms tumor gene on the X chromosome (WTX) and PALB2, a major BRCA2 binding partner, bind to Keap1, whereas p21 directly binds to Nrf2, leading to inhibition of Nrf2 ubiquitination and increased Nrf2-dependent gene expression [55-57]. This review will focus on the role of $\mathrm{Nrf} 2$ in neurodegeneration and the potential for Nrf2 activation to mitigate progression of neurological diseases.

\section{Nrf2 in Alzheimer's disease}

$\mathrm{AD}$ is an age-associated progressive neurodegenerative disorder characterized by memory loss and cognitive dysfunction and is the most common form of dementia. There are currently over 5 million AD patients in the United States and it is projected that, without the development of disease-modifying therapies, the number will increase to approximately 13.8 million by 2050 [58]. Pathological hallmarks of AD include brain atrophy due to neuronal and synapse loss, senile plaques predominantly consisting of fibrillar amyloid beta (A $\beta$ )peptide, and neurofibrillary tangles (NFT) of hyperphosphorylated tau, a cytoskeletal protein. $A \beta$ is generated from the cleavage of amyloid precursor protein (APP) by $\beta$ - and $\gamma$ - 
secretases, and it is believed that small oligomers of this self-aggregating peptide are responsible for the neuronal cell death in $\mathrm{AD}$ [59]. The major risk factor for developing $\mathrm{AD}$ is aging and most $\mathrm{AD}$ is sporadic; however, a small fraction of $\mathrm{AD}$ is familial in origin. Mutations in APP, presenilin 1 (PS1), and presenilin 2 are associated with early onset familial disease [60]. In addition to the plaques and NFT, the AD brain is characterized by mitochondrial dysfunction, reactive gliosis, and oxidative damage to lipids and proteins [36] (Marshak 1992, Smith 1997, Schipper 2006, Wang X 2007, Shaftel 2008).

\section{Nrf2 and Nrf2-dependent genes in AD brains}

Initial studies demonstrated that $\mathrm{NAD}(\mathrm{P}) \mathrm{H}$ :quinone oxidoreductase 1 (NQO1) is increased in AD compared to control tissues [61-63]. The same was found for glutathione reductase, glutathione peroxidase, and heme oxygenase 1 (HO-1) [64-66]. In addition, p62, HO-1, and glutamate cysteine ligase modifier subunit (GCLM) were increased in AD brains [67]. Tanji and colleagues [67] also demonstrated that Keap1 and p62 interact with each other and are present in both the soluble and insoluble protein fractions in AD brain, as well as showing co-localization of Keap1 with NFT. A study that examined Nrf2 via immunohistochemistry found that Nrf2 is present in both the nucleus and cytoplasm of neurons in normal hippocampi, with greater intensity in the nucleus; however, in AD, Nrf2 was confined to the cytoplasm [68]. In contrast to the previous studies, this suggests that there is reduced Nrf2 activation in the AD brain. Indeed, studies have shown that some of the same Nrf2dependent genes discussed above are reduced or do not change in AD [69-71]. These contradictory findings are not surprising and could be very dependent on the stage of disease at the time of tissue collection. In addition, our laboratory has unpublished and published data indicating that the vast majority of Nrf2-dependent genes and proteins, as well as glutathione (GSH) levels in the brain and spinal cord, are not decreased in Nrf2-/- mice $[72,73]$.

\section{Nrf2 and animal models of AD}

Multiple papers have demonstrated that Nrf2 activation can protect against $\mathrm{A} \beta$-mediated toxicity in vitro, so the following discussion will focus primarily on the in vivo data generated that support a role Nrf2 in modulating AD. The first study to examine $\mathrm{Nrf} 2$ in a mouse model of $\mathrm{AD}\left(\mathrm{APP} / \mathrm{PS} 1 ; \mathrm{APP}_{\mathrm{Swe}} / \mathrm{PS} 1 \triangle \mathrm{E} 9\right)$ demonstrated a decrease in mRNA levels of GCLM, glutamate cysteine ligase catalytic subunit (GCLC), and NQO1 at 6 months of age, as well as a reduction in Nrf2 at 16 months, using immunohistochemistry [74]. However, recent work in 7-month-old APP/PS1 mice did not see any significant changes in mRNA levels of these same genes [73]. At the protein level, there was a modest but significant increase of GCLC with no change in Keap1, NQO1, or GCLM in the APP/PS1 mice. Studies using the $3 \times$ TG model of AD also found a significant increase in NQO1 protein in hippocampus and cortex at 2 months of age, but by 6 months of age, NQO1 levels were actually significantly reduced in hippocampus [75]. Finally, nuclear Nrf2 levels were increased at 3 months and decreased at 15 months in the male cortex but unchanged in the female cortex of 3xTG mice [76]. In spite of these observations, there was no increase in GCLC and there were decreases in SOD1 (superoxide dismutase 1), HO-1, and Prdx-1 (peroxiredoxin-1) mRNA in the 3-month-old male 3xTG cortex. Overall, it is hard to argue 
that there are consistent changes in protein or mRNA in mouse models of AD, which is similar to the observations in human tissue.

Nrf2-/- mice crossed with APP/PS1 mice showed significant increases in intracellular A $\beta$, APP fragments, and full-length APP in CA1 neurons in APP/PS1/Nrf2-/- compared with APP/PS1 mice, without a clear change in plaque load [73]. Furthermore, levels of A $\beta$, APP fragments, and full-length APP in the insoluble protein fraction from hippocampus were increased in APP/PS1/Nrf2-/- mice. It has been suggested that Nrf2 is involved in regulation of autophagy via increasing p62 [77-79]. Interestingly, the same APP/PS1/Nrf2-/ - had punctate staining patterns for p62 versus a more diffuse staining in APP/PS1 mice, implying that the lack of Nrf2 in APP/PS1 mice drives p62 into more insoluble aggregates. There was an increase in the ratio of phospho-mTOR/total mTOR, as well as an increase in the ratio of phospho-p70S6k/total p70S6k in hippocampus of APP/PS1/Nrf2-/- mice compared with littermate controls, indicative of autophagy inhibition. More evidence of autophagy inhibition in APP/PS1/Nrf2-/- mice was the increase in multivesicular bodies, endosomes, and lysosomes in CA1 neuron compared with APP/PS1 mice. Jo and coworkers [80] published that tau and phosphorylated tau increase spontaneously in 6-monthold Nrf2 knockout mice [80]. Although there was no change in tau kinase or phosphatase activities in Nrf2-/- mice, there was a significant reduction in NDP52 (an autophagy adaptor protein). NDP52 contains ARE sequences and is induced by Nrf2 activating compounds that lead to a reduction of phosphorylated tau. In contrast to these data, Joshi and co-workers found no increase in tau or phosphorylated tau in either the 7-month-old Nrf2-/- mice or APP/PS1/Nrf2-/- (unpublished data).

An antisense oligonucleotide approach targeting GSK3 $\beta$ has been done in the SAMP8 AD model [81]. As mentioned earlier, Nrf2 turnover can be regulated by the GSK3 $\beta / \beta-\operatorname{TrCP}$ pathway, and inhibition of GSK3 $\beta$-mediated phosphorylation of Nrf2 would prevent the binding of $\beta-\operatorname{TrCP}$ and subsequent Nrf2 degradation via this pathway. The treatment increased nuclear Nrf2 and glutathione s-transferase (GST) levels. This correlated with improved behavior, reduced nuclear and cytoplasmic GSK3 $\beta$, reduced protein carbonyl and protein bound 4-hydroxynonenal (HNE), and reduced phosphor-tau. Lentivirus (LV) was used to deliver Nrf2 intrahippocampally [82]. LV-Nrf2 was stereotactically injected bilaterally into the hippocampus of 9-month-old transgenic APP/PS1 mice. Spatial learning deficits of aged APP/PS1 mice in a Morris water maze were significantly improved by LVNrf2 compared with LV-GFP. There was also a reduction in astrocytic but not microglial activation and increased neuronal HO-1 up to 6 months postinjection. Finally, earlier studies in our laboratory had demonstrated that Nrf2 activation in astrocytes could confer protection from oxidative-stress-induced death on neurons [83, 84]. Based on these observations and to further address the potential role of astrocytic Nrf2 activation providing neuroprotection in neurodegenerative diseases, transgenic mice were generated that selectively overexpressed Nrf2 in astrocytes [85]. The glial fibrillary acidic protein (GFAP) promoter was used to drive Nrf2 expression in astrocytes. These GFAP-Nrf2 mice have been crossed with APP/PS1 and mutant tau mice to determine if astrocytic Nrf2 activation can mitigate the AD-like pathogenesis in these mouse models. 
Many compounds and natural products have been identified as Nrf2 activators. CDDOmethylamide (CDDO-MA) improved memory and decreased plaques, $\mathrm{A} \beta(1-42)$, and markers of oxidative stress in the $\operatorname{Tg} 19959$ mice [86]. Puerarin, a phytoestrogen with antioxidant properties, was shown to improve the phenotype of APP/PS1 mice [87]. The effect was attributed to preventing the activation of GSK3 $\beta$, thus preventing proteasomal degradation of Nrf2 through the $\beta$-TrCP pathway. Gracilins A and C, Spongionella-derived compounds shown to activate Nrf2 and have antioxidant properties, have shown some benefit in 3xTG mice [88]. A number of recent papers have used what they refer to as an acute model of $\mathrm{AD}$ by directly injecting $\mathrm{A} \beta(1-40)$ or $\mathrm{A} \beta(1-42)$ into the hippocampus. When compounds were administered prior to the injection of $A \beta$, beneficial effects were noted for SuHeXiang essential oil [89], sulforaphane [90, 91], $\beta$-hydoxybutyrate [92], orientin [93], and baicalin [94]. A major caveat to all the studies discussed in this section is that none of them were done in Nrf2-/- or knockdown mice to clearly demonstrate that these same compounds being tested require Nrf2 for their therapeutic effects.

\section{Nrf2 in Parkinson's disease}

PD is the most common neurodegenerative movement disorder, characterized by motor symptoms such as tremor, bradykinesia, posture instability, and rigidity and a number of nonmotor neuropsychiatric problems [95]. One pathological hallmark of PD is the loss of dopaminergic neurons in the substantia nigra pars compacta $(\mathrm{SN})$, resulting in reduced levels of dopamine nerve terminals projecting to the striatum. A second hallmark is the formation of intracellular inclusions made up primarily of alpha-synuclein (SYN) bound to ubiquitin, also referred to as Lewy bodies (LB) [96-98]. As with AD, the majority of PD cases are sporadic, with familial cases accounting for about $15 \%$ of PD [99]. Numerous genes are associated with familial PD, including a-SYN, parkin, leucine-rich repeat kinase 2 (LRRK2), PTEN-induced putative kinase 1 (PINK1), and DJ1 [100]. Similarly to sporadic and familial cases of $\mathrm{AD}$, the pathologic hallmarks for $\mathrm{PD}$ are present in both sporadic and most cases of familial cases of PD. Thus, the familial cases of PD and AD are, for the most part, an accelerated early onset version of sporadic disease.

\section{Nrf2 and Nrf2-dependent genes in PD brains}

It has been noted that NQO1 is up-regulated in astrocytes, endothelial cells, and dopaminergic neurons in human PD brain [101]. A similar pattern is observed with HO-1 and peroxiredoxin in SN of PD patients [102-104]. Immunostaining for Nrf2 demonstrated nuclear localization of Nrf2 in dopaminergic neurons of PD brains [68]. Oxidative stress has been implicated in PD along with mitochondrial dysfunction, protein carbonyls, and oxidative DNA damage in the SN [4, 14, 22]. GSH levels are also reduced in PD brain [105, 106]. In addition, Keap1 is co-localized with SYN and p62 in LB of PD brain [67]. A recent study in induced pluripotent stem cells (iPSC)-derived from PD and control patients also supports Nrf2 involvement in PD. Neurons differentiated from the PD iPSC had reduced GSH, increased oxidative stress, increased Nrf2 activation, and increased NQO1 levels [107]. 


\section{Nrf2 and animal models of PD}

In the 1-methyl-4-phenyl-1,2,3,6-tetrahydropyridine (MPTP) model, Chen and colleagues determined changes in mRNA and measured NQO1 and hPAP (human placental alkaline phosphatase) activity [108]. The ARE-hPAP reporter mice have a 51-base-pair segment of rat NQO1 promoter containing the core ARE that was inserted into a TATA-Inr minimal promoter:hPAP reporter gene construct [109]. The SN had increased hPAP and NQO1 activity, as well as increased mRNA levels of Nrf2, NQO1, GCLC, GCLM, and HO-1 following MPTP [108]. In contrast, hPAP and NQO1 activity were reduced in striatum, along with decreased mRNA for Nrf2 and NQO1. GCLC, GCLM, and HO-1 remained unchanged. Another study found an increase in striatal protein levels of Nrf2 and increased mRNA amounts for GCLC, GCLM, and HO-1 [110]. Finally, Innamorato et al. showed increases in NQO1, GCLM, GCLC, and HO-1 protein, as well as HO-1 mRNA level in striatum [111]. These discrepancies may be due to the method of MPTP administration. In the first study, MPTP $(30 \mathrm{mg} / \mathrm{kg}$ ) was administered once a day for five days, with tissues being harvested seven days after the last dose [108]. The second study administered MPTP (4 mg/kg) for 20 days [110] and the third at $30 \mathrm{mg} / \mathrm{kg}$, once a day, for five days with tissue being harvested immediately after the last dose [111]. Others have directly injected MPP+ into the brain and shown decreased SN levels of Nrf2 and GCLC protein [112]. Using the same MPP+ method, others found decreased Nrf2 DNA binding, no change in Nrf2 or GCLC, and increased HO-1 protein levels in SN [113]. This group also determined that there was no change in Nrf2 DNA binding, decreased Nrf2 and GCLC protein, but increased HO-1 protein in striatum. In the 6-hydroxydopamine (6-OHDA) model of PD, only a few studies could be identified. One study using ARE-hPAP mice demonstrated increased Nrf2 activity in striatum seven days following injection [114]. A second study determined that protein levels of both Keap1 and Nrf2 were decreased in striatum [115]. Obviously, the data are not consistent and more studies need to be performed to sort out how the Nrf2 pathway is responding to the toxin models of PD.

In transgenic mouse models of PD, only two papers could be found that directly investigated how familial protein overexpression affected the Nrf2 pathway [116, 117]. Gan and coworkers used the Thy1-hSYN ${ }^{\mathrm{A} 53 \mathrm{~T}}$ PD mouse model and evaluated changes at two and six months of age (symptomatic and nonsymptomatic). Since the synucleinopathy in these mice presents in spinal cord with motor neuron loss, only the spinal cords were examined. In nonsymptomatic mice, significant but modest changes were noted at two months (15\% increase in GCLM), with only NQO1 increasing (1.5-fold mRNA; 2.6-fold protein) and a $10 \%$ increase in GSH at six months. In symptomatic six-month-old mice, a trend of reduced GSH that correlated with a 20-30\% reduction in GCLM and GCLC mRNA levels was observed [116]. These same mice were also crossed with the ARE-hPAP reporter mice, which demonstrated increased hPAP staining in the ventral horn of the spinal cord. The second study used mice with the tyrosine hydroxylase $(\mathrm{TH})$ promoter driving hSYN ${ }^{\mathrm{WT}}$ for targeted expression in the dopaminergic neurons [117]. At one month of age NQO1, GCLM, GCLC, and HO-1 were increased ranging from 1.6- to 2.0-fold in the SN and 2.1- to 2.5-fold in striatum. However, by the age of six months, all changes returned to control levels. 
Early experiments utilized Nrf2-/- mice to show increased sensitivity to the dopaminergic toxins MPTP and 6-OHDA [118, 119]. The increased sensitivity of the Nrf2-/- mice to MPTP has been repeated in multiple laboratories [108, 111, 120-122]. In general, there is a greater loss of TH and reduction of dopamine (DA), as well as the dopamine metabolites 3,4-dihydroxyphenylaceticacid (DOPAC) and homovanillic acid (HVA). There is increased neuroinflammation associated with greater astrocyte (GFAP) and microglial (Iba-1; ionized calcium binding adaptor molecule 1) activation in Nrf2-/- mice. It is also important to note that the basal level of mRNA expression and protein content of Nrf2-dependent genes remained unchanged $[108,121]$ or slightly reduced [122] in striatum and SN (ventral midbrain) of the Nrf2-/- compared to control mice. This strongly suggests that the primary role for Nrf2 in the central nervous system is to respond to insults by activation of gene expression. Thus, the lack of an Nrf2 response in Nrf2-/- mice leads to greater damage in the mouse brain. Interestingly, it is hypothesized that Nrf2 responsiveness is attenuated with age, reducing the endogenous Nrf2 response to oxidative stress similarly to what is most likely occurring in the Nrf2-/- mice. Adeno-associated virus (AAV) has been used to deliver hSYN ${ }^{W T}$ (AAV-hSYN ${ }^{W T}$ ) to Nrf2+/+ and Nrf2-/- mice [123]. AAV-hSYNWT was stereotactically injected into the ventral midbrain and tissues were harvested 2 months after injection. There was a small but significant loss of TH-positive neurons in both $\mathrm{Nrf} 2+/+$ and Nrf2-/-, with slightly more loss (23\% more) in the Nrf2-/- mice. However, there were no changes in DA, DOPAC, or HVA. The authors speculate that the Nrf2 pathway may be involved in SYN degradation through the ubiquitin-proteasome system (UPS) but the mRNA levels of the proteasome subunits PSMB7, PSMC3, and PSMC4 in the ventral midbrain were not significantly different between $\mathrm{Nrf} 2+/+$ and $\mathrm{Nrf} 2-/-$ mice.

Immunohistochemical analysis for PSMB7 allowed evaluation of the dopaminergic neurons, which stained positive for hSYN ${ }^{\mathrm{WT}}$ and PSMB7. These data did suggest that there are differences in neuronal PSMB7 in Nrf2+/+ and Nrf2-/- mice. There were also changes in astrocytic and microglial activation based on cellular morphology without biochemical validation. Based on early studies showing the importance of Nrf2 activation in astrocytes $[83,84]$, Jakel and co-workers transduced astrocytes in vitro with adenovirus containing Nrf2 (Ad-Nrf2) or GFP (Ad-GFP) and then transplanted these Nrf2-overexpressing and control GFP astrocytes into the ipsilateral and contralateral striatum, respectively, by stereotactic injection [119]. Five weeks later, bilateral injection 6-OHDA toxicity revealed a significantly reduced lesion volume in the Nrf2 astrocyte striatum. To better understand if astrocytic Nrf2 activation can modulate PD, GFAP-Nrf2 mice were treated with MPTP. Dramatic protection of the dopaminergic neurons was observed in the GFAP-Nrf2 mice following MPTP administration, which was sustained when the GFAP-Nrf2 mice were on an Nrf2-/- background [108]. GFAP-Nrf2 mice were then crossed with the Thy1hSYNA53T to evaluate if Nrf2 overexpression in astrocytes could modulate hSYNA53T aggregation and proteostasis [116]. The median survival of the hSYN ${ }^{\mathrm{A} 53 \mathrm{~T}}$ mice was dramatically extended by Nrf2 overexpression in astrocytes from 206.5 days in hSYN ${ }^{A 53 T}$ mice to 272.0 days in $\mathrm{hSYN}^{\mathrm{A} 53 \mathrm{~T}} / \mathrm{GFAP}-\mathrm{Nrf} 2$ double transgenic mice. During pathogenesis, hSYN ${ }^{\mathrm{A} 53 \mathrm{~T}}$ shifted from the soluble to the insoluble/aggregated protein fraction. Six-month-old symptomatic hSYN ${ }^{A 53 T}$ mice had a significant increase in insoluble/aggregated $\mathrm{hSyn}^{\mathrm{A} 53 \mathrm{~T}}$ that was completely reversed by overexpression of $\mathrm{Nrf} 2$ in 
astrocytes. The insoluble hSYN ${ }^{\mathrm{A} 53 \mathrm{~T}}$ was also highly phosphorylated (Ser129) (p$\mathrm{hSYN}^{\mathrm{A} 53 \mathrm{~T}}$ ) and immunohistochemically co-localized with hSYN ${ }^{\mathrm{A} 53 \mathrm{~T}}$ aggregates and $\mathrm{p} 62$. Again, these observations were completely reversed by GFAP-Nrf2. Autophagic dysfunction was also observed in the in $\mathrm{hSYN}^{\mathrm{A} 53 \mathrm{~T}}$ mice. Reduced macroautophagy, as well as impaired chaperone-mediated autophagy, was noted in the hSYN ${ }^{\mathrm{A} 53 \mathrm{~T}}$ mice. Astrocytic Nrf2 activation prevented neuronal autophagic dysfunction and correlated with increased lifespan and reduced $\mathrm{hSYN}{ }^{\mathrm{A} 53 \mathrm{~T}}$ aggregation in the $\mathrm{hSYN}{ }^{\mathrm{A} 53 \mathrm{~T}} / \mathrm{GFAP}-\mathrm{Nrf2}$ mice. These data suggest that Nrf2 activation in astrocytes stabilizes proteostasis and reduces oxidative stress in neurons overexpressing $\mathrm{hSYN}^{\mathrm{A} 53 \mathrm{~T}}$. The question of how this works mechanistically remains to be answered.

Numerous Nrf2-activating compounds have been tested in animal models of PD (Table 1). In general, the data show different degrees of protection of dopaminergic neurons in rats or mice. Three papers used Nrf2-/- mice to show that the protective effects of the chemical being tested were Nrf2-dependent [118, 121, 122]. Burton and colleagues demonstrated that activation of the Nrf2 pathway by oral administration of 3H-1,2-dithiole-3-thione (D3T) to wild-type mice partially protected them from MPTP-induced neurotoxicity. This protective effect was not observed in Nrf2-/- mice. Sulforaphane treatment also showed partial protection in Nrf2+/+ mice that was not observed in Nrf2-/- mice [121]. In addition, of the verified Nrf2-dependent compounds, CDDO-EA (CDDO-EA) and CDDO-

trifluoroethylamide (CDDO-TFEA) had significant effects across all endpoints measured in an MPTP study. A more recent study did not examine a compound but evaluated whether treadmill exercise could regulate $\mathrm{Nrf} 2$ and modulate $\mathrm{MPP}^{+}$pathology in rats [113]. Exercised rats were run $60 \mathrm{~min} /$ day, 5 days a week, for 4 weeks. Sedentary rats were placed on the treadmill for $60 \mathrm{~min} /$ day without running. $\mathrm{MPP}^{+}$was injected into the striatum and the rats were harvested 1 week after injection. The loss of TH-positive neurons and TH protein levels was completely reversed by exercise. LV-shNrf2 striatal injection 1 week prior to $\mathrm{MPP}^{+}$injection reversed the protective effects of exercise.

\section{Nrf2 in amyotrophic lateral sclerosis}

Amyotrophic lateral sclerosis (ALS) is the most common adult-onset motor neuron disease, caused by the progressive degeneration of motor neurons in the spinal cord, brain stem, and motor cortex [[124]. Motor neurons contain ubiquitin-positive hyaline and skein-like inclusions [125]. These inclusions contain SOD1 that co-localizes with p62 [126]. TDP-43 (TAR DNA-binding protein)- and FUS-positive inclusions have also been identified in ALS $[127,128]$. As with AD and PD, the majority of ALS cases are sporadic (sALS), with approximately $10-15 \%$ of cases associated with familial mutations (fALS). The first mutant gene identified in fALS was $\mathrm{Cu} / \mathrm{Zn}$-superoxide dismutase 1 (SOD1) and the mutation caused disease through a toxic gain of function [129]. Over 150 mutations have been identified in SOD1. Rodents overexpressing mutated forms of hSOD1 generally develop an ALS-like phenotype [130, 131]. Although the molecular mechanism underlying this toxic gain of function remains unknown, toxicity to motor neurons requires mutant SOD1 expression in non-neuronal cells as well as in motor neurons [132]. In recent years, 24 additional genes have been associated with sALS and fALS [133] including p62 [134], which has a direct link to Keap1/Nrf2 and autophagy. 


\section{Nrf2 and Nrf2-dependent genes in ALS brains}

Nrf2 and Keap1 have been examined in the primary motor cortex and spinal cord of ALS patients [135]. There was a reduction in Nrf2 mRNA and protein in ALS patient tissue relative to Nrf2 levels in control tissues, but Keap1 mRNA and protein levels did not change. Nrf2-dependent genes were not evaluated. In addition, Keap1 has been shown to colocalize with intracellular inclusions in motor neurons of postmortem ALS spinal cord [67].

\section{Nrf2 in animal models of ALS}

Initial studies in the hSOD $1^{\mathrm{G} 93 \mathrm{~A}}$ rat model of ALS demonstrated that both the mRNA and protein levels of HO-1 and Nrf2 were increased in spinal cord compared to those in nontransgenic littermate controls [136]. Interestingly, both Nrf2 and HO-1 co-localized with reactive astrocytes in the degenerating spinal cord of $\mathrm{hSOD} 1 \mathrm{G} 93 \mathrm{~A}$ rats, leading to speculation that Nrf2 activation in astrocytes may be involved in determining motor neuron fate in ALS. This concept was tested in vitro by demonstrating that Nrf2 activation in primary astrocytes increased survival of co-plated purified primary motor neurons and protected the motor neurons from a variety of insults causing motor neuron death [85, 136138]. In the hSOD1 ${ }^{\mathrm{G} 93 \mathrm{~A}}$ mouse, protein levels of Nrf2, thioredoxin, HSP-70, HO-1, NQO1, GCLC, and GCLM increased with disease progression in lumbar spinal cord but not cortex $[139,140]$. Finally, the hSOD $1^{\mathrm{G} 93 \mathrm{~A}}$ and $\mathrm{hSOD} 1^{\mathrm{H} 46 \mathrm{R} / \mathrm{H} 48 \mathrm{Q}}$ ALS models were both crossed with the ARE-hPAP reporter mice [141]. The earliest and most significant activation of this genetic sensor of Nrf2 activation occurred in the distal muscles of both mutant SOD mice. Subsequently, Nrf2 activation proceeded pathology in a retrograde fashion along the motor pathway. In the muscles of hSOD1 ${ }^{\mathrm{G} 93 \mathrm{~A}}$ mice, gastrocnemius was the first muscle to show activation at 30 days, followed by the triceps at 60 days, and intercostal muscles at 110 days. Interestingly, Nrf2 activation was isolated to type I fibers, which are known to be more resistant to degeneration than type II fiber in ALS patients. Significantly increased hPAP staining was also observed in the motor neurons and astrocytes in the ventral horn of the spinal cord. Thus, it appears that Nrf2 activation in the muscle is in response to denervation and occurs prior to Nrf2 activation in spinal cord.

Nrf2 knockout mice have been crossed with the hSOD1 ${ }^{\mathrm{G} 93 \mathrm{~A}}$ and hSOD1 ${ }^{\mathrm{G} 85 \mathrm{R}}$ models of ALS $[140,142]$. The first study found a modest decrease in lifespan by six days in male and seven day in female hSOD1 ${ }^{\mathrm{G} 93 \mathrm{~A}}$ mice on an Nrf2-/- background [140]. In the second study, Nrf2 knockout had no effect on lifespan or onset in the hSOD1 ${ }^{\mathrm{G} 93 \mathrm{~A}}$ and hSOD1 ${ }^{\mathrm{G} 85 \mathrm{R}}$ mice [142]. Viral-mediated therapy was performed using intramuscular injection of AAV6Nrf2. The virus can transduce axons at the neuromuscular junction, followed by axonal retrograde transport and expression of Nrf2 in motor neuron cell bodies [143]. The hSOD1 ${ }^{\text {G93A }}$ mice were injected with either AAV6-Nrf2 or AAV6-GFP at 30 days of age in multiple muscles (facial, tongue, intercostal, diaphragm, and hind limbs). No effect on lifespan, onset, motor neuron survival, or rotarod performance was observed. The negative results were attributed to low viral transduction efficiency of motor neurons. Although this may be the case, another study using transgenic mice to drive Nrf2 overexpression in neurons also resulted in a negative outcome [142]. Here, these investigators crossed the Thy1-cre, hSOD1 ${ }^{\mathrm{G} 93 \mathrm{~A}}$, and caNrf2 mice. The caNrf2 mice carry an Nrf2 transgene that lacks the N-terminal Neh2 domain responsible for binding to Keap1 under control of the 
chicken $\beta$-actin promoter. Between the promoter and caNrf2 lies a transcription/translation STOP cassette flanked by loxP sites. In the presence of cre recombinase the STOP is removed and caNrf2 is expressed. Thy 1 promoter is a neuronal selective promoter driving the expression of cre recombinase, which allowed the overexpression of caNrf2 in neurons. Although neuronal overexpression of caNrf2 in hSOD1 ${ }^{\mathrm{G} 93 \mathrm{~A}}$ led to a significant seven-day delay in onset, there was no significant effect on survival. Based on the ARE-hPAP expression profile in $\mathrm{hSOD} 1{ }^{\mathrm{G} 93 \mathrm{~A}}$ mice discussed earlier, overexpression of $\mathrm{Nrf} 2$ in the degenerating type II fiber was hypothesized. Transgenic mice were generated using the MLC1 (myosin light chain 1) promoter driving expression of Nrf2 selectively in type II fiber of skeletal muscle [142]. Similarly to the neuronal overexpression of Nrf2, there was a significant eight-day delay in onset, but no significant effect on survival. The most compelling data come from experiments using transgenic GFAP-Nrf2 mice that overexpress Nrf2 only in astrocytes [85]. Crossing these mice with the hSOD1 ${ }^{\mathrm{G} 93 \mathrm{~A}}$ and hSOD $1{ }^{\mathrm{H} 46 \mathrm{R} / \mathrm{H} 48 \mathrm{Q}}$ mice significantly delayed onset by 17 days and extended lifespan by 20.5 days. Furthermore, a delay in astrogliosis, but more importantly a significant attenuation of microglial activation, was observed. Finally, there was reduced neuronal loss and muscle denervation in the GFAP-Nrf2/hSOD $1^{\mathrm{G} 93 \mathrm{~A}}$ mice.

The published data on Nrf2-activating compounds has been more limited in ALS than in PD. This may be a reflection of either a lack of experimental studies using Nrf2-activating compounds or the failure of these compounds, because of which no studies have been published. For example, sulforaphane has been used and failed without publication (personal communication). Some of the same compounds used in PD models, CDDO-EA and CDDOTFEA, have been used in ALS models [144]. These compounds were fed in the diet and feeding was initiated at 30 and at 75 days of age (onset) to hSOD ${ }^{\mathrm{G} 93 \mathrm{~A}}$ mice. The former treatment protocol resulted in an extension of lifespan by 20.6 days for CDDO-EA and 17.6 days for CDDO-TFEA. The latter treatment protocol resulted in an extension of lifespan by 17.5 days for CDDO-EA and 16 days for CDDO-TFEA. Feng and colleagues tested DL-3-nbutylphthalide in $\mathrm{hSOD} 1^{\mathrm{G} 93 \mathrm{~A}}$ mice [145]. The compound was administered by gavage once a day starting at onset, and there was a significant extension of lifespan at the highest dose of approximately 18 days. This was accompanied by increased neuronal survival and suppression of neuroinflammation (astrocytic and microglial activation). S-[+]-apomorphine was identified as an Nrf2 activator in a compound screen and used to treat hSOD1 ${ }^{\mathrm{G} 93 \mathrm{~A}}$ mice [146]. Drug treatment was started at 21 days until end stage. Although, there was some delay in onset and behavioral outcome measures, there was no effect on lifespan. CPN-9 was identified through an in silico drug screen to identify compounds that suppress oxidative stress-induced cell death and was subsequently shown to be an Nrf2-activating compound [147]. hSOD $1^{\mathrm{H} 46 \mathrm{R}}$ mice were treated with $\mathrm{CPN}-9$ by gavage at the day of onset, demonstrating a small, but significant, six-day extension of lifespan at the highest dose of CPN-9. Finally, the same group produced a novel acylaminoimidazole derivative, WN1316, based on the structure of CPN-9 that retained Nrf2 activity [148]. The hope was to develop a compound with better pharmacokinetics for the treatment of ALS. Again, treatment was initiated at onset in both the hSOD $1^{\mathrm{H} 46 \mathrm{R}}$ and $\mathrm{hSOD} 1^{\mathrm{G} 93 \mathrm{~A}}$ mice and a significant extension of survival of hSOD $1^{\mathrm{H} 46 \mathrm{R}}$ by nine days and $\mathrm{hSOD} 1^{\mathrm{G} 93 \mathrm{~A}}$ by eight days was seem at the 
highest dose of WN1316. In addition, a delay in neuronal loss, as well as astrocytic and microglial activation, was observed.

\section{Nrf2 in Huntington's disease}

$\mathrm{HD}$ is an autosomal dominant neurodegenerative disease that is associated with expansion of a CAG repeat in the gene encoding the Htt protein [149]. This results in a stretch of $\mathrm{N}$ terminal glutamine residues, and the severity and onset of disease correlates with the length of this polyglutamine repeat. Furthermore, a conformational change in the mutant Htt increases self-aggregation associated with intracellular inclusion formation [150]. HD is pathologically characterized by degeneration in neostriatal (caudate and putamen) and cerebral cortex that is believed to be the underlying contributor to motor impairment, cognitive decline, and psychiatric symptoms, which worsen as the disease progresses. Oxidative stress due to mitochondrial dysfunction has been implicated in human patients [151]. Defects in mitochondrial complex II, III, and IV were observed in striatum of postmortem HD brain [152, 153].

\section{Nrf2 and Nrf2-dependent genes in HD brains}

Surprisingly little work has been done on HD tissues and Nrf2. There has been only one study examining Nrf2 or Nrf2-dependent genes in postmortem HD brains [154], in which HO-1 immunohistochemical staining was increased in HD brain.

\section{Nrf2 in animal models of HD}

Malonate and 3-nitropropionic acid (3NP), mitochondrial complex II inhibitors, produce striatal medium spiny neuron degeneration, a characteristic feature observed in HD [155, 156]. Malonate-treated ARE-hPAP reporter mice show significant increases in hPAP activity in astrocytes that form the border of the penumbra [157, 158]. Malonate also increased Nrf2 and HO-1 mRNA levels in mouse striatum seven days after injection into striatum [158]. In the 3NP model, HO-1 and NQO1 protein levels were increased in rat striatum [159]. However, another study using 3NP did not demonstrate changes in Nrf2 protein or mRNA levels of NQO1, HO-1, GCLM, or glutathione-S-transferase P1 [160]. The Nrf2-depdendent subunit of system $\mathrm{x}_{\mathrm{c}}{ }^{-}$(a cystine transport system), $\mathrm{xCT}$, is reduced in R6/2 striatum, suggesting the possible disruption of Nrf2 activity in the mouse model [161]. Expanding on the role of Nrf2 in the malonate and 3NP HD models. Nrf2-/- mice exposed to these agents had more significant lesion volumes at doses that had little or no effect in wild type mice $[157,162,163]$.

In addition, Calkins and colleagues demonstrated that Ad-Nrf2-, in contrast to Ad-GFPtransduced primary astrocyte and mouse neural progenitor cells transplanted into the mouse striatum had significant protection form malonate toxicity $[157,158]$. Four to five weeks after transplantation of both cell types, the mice were injected with malonate and Ad-Nrf2 transplants had an 80-90\% reduction in lesion volume. Direct injection of Ad-Nrf2 into the striatum also conferred significant but less protection against 3NP toxicity [162]. Malonate was also injected into the striatum of GFAP-Nrf2 mice, and similarly, the GFAP-Nrf2 mice were more resistant to malonate [158]. Interestingly, there was no difference in baseline 
levels of Nrf2-dependent genes in GFAP-Nrf2 striatum. In addition, astrocytic and microglial activation were not attenuated. However, there was dramatic acceleration and robust Nrf2 activation that occurred within $24 \mathrm{~h}$ of malonate dosing in the GFAP-Nrf2 mice. In contrast, the wild type mice had virtually no increased Nrf2, suggesting that activation of the Nrf2 pathway after a toxic insult could be beneficial.

Similarly to PD and ALS models, the CDDO-MA has been tested in the 3NP model, whereas CDDO-EA and CDDO-TFEA have been tested using the N171-82Q mouse model of HD [164, 165]. In all cases, significant protection was observed. The N171-28Q mice were started on diets containing the CDDO compounds at 30 days of age. Lifespan was increased 34 and 29 days for CDDO-EA and CDDO-TFEA, respectively. However, Nrf2-/mice were not used in these studies. Another group fed tert-butylhydroquinone (tBHQ), a well-known Nrf2-activating compound, to Nrf2+/- and Nrf2-/- mice followed by $3 \mathrm{NP}$ administration [162]. tBHQ was started 1 week prior to starting the $3 \mathrm{NP}$, and the data showed protection with tBHQ in Nrf2+/- but not Nrf2-/- mice. A similar experiment gave cystamine once daily for seven days to Nrf2+/+ and Nrf2-/- mice prior to starting $3 \mathrm{NP}$ dosing [163]. The Nrf2+/+ mice given cystamine did not have any striatal lesions, and in the Nrf2-/-, cystamine actually significantly increased lesion volume. The R6/2 and YAC128 models of HD were treated with dimethylfumarate (DMF), another known Nrf2-activating compound [166]. DMF dosing twice daily via gavage began at 4 weeks of age in the R6/2 mice. Survival was extended from 94 to 100.5 days and was associated with preserved muscle function and body weight, as well as increased number of intact neurons. Formation of intracellular ubiquitin-positive Htt aggregates, however, was not affected by DMF treatment. DMF treatment of YAC128 mice resulted in reduced clasping score and neuronal loss in the striatum and cortex at 1 year of age. Two additional compounds, naringin, a flavonone from grapefruit, and protopanaxtriol, a compound isolated from ginseng, protect against 3NP-induced neurodegeneration [159, 160]. Much more work is required in the HD and genetic HD models to better understand how Nrf2 can modulate HD pathology. Current work in our laboratory is examining the protective effects of neuronal versus astrocytic Nrf2 overexpression in R6/2 transgenic and zQ175 knockin mice.

\section{Nrf2 in multiple sclerosis}

It is estimated that as many as 400,000 people in the United States and more than 2.3 million people worldwide are affected by multiple sclerosis (MS). MS is a chronic neuroinflammatory disease onset by activation of peripheral $\mathrm{CD} 4^{+} \mathrm{T}$ cells that traverse the blood-brain barrier and mount a damaging autoimmune attack on myelin and oligodendrocytes in the central nervous system (CNS) [167]. Neurological deficits manifest in heterogenic conditions that include but are not limited to vision loss, dyscoordination, weakness, sensory loss, and cognitive changes, as well as bladder and bowel dysfunction. Pathology of MS is attributed to the pathogenic attack on myelin sheathing and oligodendrocytes by autoreactive $\mathrm{CD} 4^{+} \mathrm{Th} 1$ and $\mathrm{Th} 17$ cells, as well as infiltrating macrophages and resident microglia, resulting in axonal retraction and astrogliosis. The reactive microglia and astrocytes, in turn, secrete inflammatory mediators that not only include cytokines and chemokines, but also produce reactive oxygen and nitrogen species that contribute to oxidative stress, exacerbating the already deleterious effects of the 
neuroinflammatory-associated tissue damage contributing to the disease progression [168, 169]. Today, there are currently eight therapies approved by the FDA for the treatment of relapsing remitting MS, the most common ( $~ 87 \%$ of MS patients) of the four clinical forms of this disease, which focus primarily on preventing the penetration of immune cells across the blood-brain barrier. However, the extreme complexity and heterogeneity of the disease, therapy resistance developed over time, and the more current dogma that oxidative stress contributes to the disease, warrants further investigation to improve and/or contribute to existing treatments [170].

\section{Nrf2 and Nrf2-dependent genes in MS brain lesions}

Severe oxidative damage has been observed in lesions from MS brain tissue and attributed to the inflammatory-mediated generation of reactive oxygen and nitrogen species.

Expression of antioxidant proteins and enzymes, as well as Nrf2 protein, coincided with cellular stress markers in active lesions when compared with normal-appearing white matter (NAWM) and white matter tissue from non-neurological control brains [171-173]. Thus, activation of an Nrf2-mediated antioxidant response may reflect protective cellular defense mechanisms against the oxidative stress-mediated damage associated with persistent inflammation. Initial studies identified NQO1, a well-known Nrf2-regulated enzyme, as highly up-regulated in active and highly active MS lesions, particularly in hypertrophic astrocytes and myelin-laden macrophages. Oligodendrocytes sporadically displayed NQO1 immunnoreactivity, while neuronal NQO1 staining was rarely observed [171]. Subsequent studies identified active MS lesions as being immunoreactive for the oxidative stress markers 4-HNE, 8-hydroxydeoxyguanosine, and nitrotyrosine, with these same active lesions coexpressing the antioxidant enzymes HO-1, SOD1, SOD2, and catalase. Similarly to the expression of NQO1, this staining was morphologically and histochemically identified as being present in hypertrophic astrocytes and myelin-laden macrophages with modest or no staining in NAWM. Consistent with the expression of antioxidants, up-regulation of Nrf2 in MS lesions was localized to both the nucleus and cytoplasm of infiltrating macrophages and reactive astrocytes, with weak expression in oligodendrocytes bordering active lesions [173].

\section{Nrf2 and animal models of MS}

Studies using mouse models of multiple sclerosis indicate the importance of Nrf2 in the progress and/or prevention of this demyelinating neuroinflammatory disease. For instance, Nrf2 knockout mice immunized with myelin oligodendrocytic protein (MOG 35-55) to induce an acute autoimmune experimental autoimmune encephalomyelitis (EAE), a humanized model of MS in mice, demonstrated a more severe course of disease, a more rapid onset, and a greater percentage of Nrf2 knockout mice with EAE. In spines from diseased mice, there were more severe demyelination and increased immune cell infiltration and glia cell activation, as well as increased mRNA expression of inflammatory enzymes (iNOS, phox-47, gp91-phox, and phox-67), cytokines (IFN-gamma, IL1-b, and IL-12) and chemokines $(B L C$ and $M I G)$, in Nrf2-deficient mice than in WT mice, further suggesting that Nrf2 can modulate autoimmune neuroinflammatory responses [174]. 
More recently, compound- or natural product-mediated activation of the Nrf2 signaling pathway has been found to ameliorate oxidative stress and neuroinflammation in EAE and MS [175-178], supporting the notion that induction of Nrf2 in both mouse and human can prevent or alleviate the pathogenesis associated with MS and EAE. Remarkable examples are the fumaric acid esters (FAE), methyl hydrogen fumarate (MHF), and dimethyl fumarate (DMF). These were previously used for effective treatment of the autoimmune skin disorder psoriasis via immunomodulation and immunosuppression. Treatment with DMF also had a significant therapeutic effect on clinical scores of disease and reduced macrophage inflammation in spinal cords of EAE mice versus control treatments [179]. Interestingly, in early studies using murine primary astrocytes, DMF, a strong glutathione-depleting agent, had been shown to activate the Nrf2-ARE pathway [180]. Both DMF and MMF (a primary metabolite of DMF) have been shown to react with the Keap1 cysteine 151 residue (cys151) in studies using Keap1-C151S mutant macrophages and mass spectrometric analysis of astrocytes, respectively [175, 181]. It was further demonstrated that the FAE indeed had neuroprotective effects in EAE via activation of the Nrf2 pathway. Preventative or therapeutic (after disease was initiated) application of DMF attenuated disease severity and improved preservation of myelin, axons, and neurons, which did not occur in Nrf2-/- mice. Immunoreactivity for protein nitrosylated tyrosines, indicative of oxidative stress, was reduced in spinal cord sections from mice with EAE by treatment with DMF. Furthermore, induction of Nrf2 in neurons of the motor cortex and brainstem, astrocytes of spinal cord gray matter, and oligodendrocytes from spinal cord white matter was observed [175]. Treatments of animals or primary cultures of CNS cells with DMF or MMF resulted in increased levels of Nrf2 nuclear localization, as well as increased levels of canonical antioxidant target genes that were not observed in Nrf2 knockout mice [182]. DMF (BG-12) has proved effective in Phase III clinical trials for the treatment of relapsing MS and was approved for use by the FDA in March of 2013. Importantly, biopsies from a patient with MS, as well as three psoriasis patients with progressive multifocal leukoencephalopathy (single cases in connection with FAE treatments), identified astrocytes as staining positive for both nuclear and cytoplasmic Nrf2, whereas oligodendrocytes had mostly cytoplasmic staining and only on single occasions nuclear Nrf2 staining [183]. Thus, although FAE indeed modulate immune function in MS, activation of the Nrf2 signaling pathway may also be an important mechanism of action for the prevention of oxidative-stress-induced neuronal toxicity.

In addition to the FAE, several more recent studies using natural compounds such as sulforaphane, an organosulfur compound found in cruciferous vegetables, and matrine, a quinolizidine alkaloid derived from the herb Sophora flavescens, as well as CDDO-TFEA, a derivative of the natural triterpene oleanolic acid, have all been identified as attenuating EAE through Nrf2-modulatory, as well as immunomodulatory mechanisms [176-178]. More specifically, sulforaphane was shown to ameliorate EAE by preserving the bloodbrain barrier, reducing the levels of the autoimmune $\mathrm{T}$ cell, Th17, in addition to antagonizing oxidative stress via activation of $\mathrm{Nrf} 2$, as evidenced by increased expression of NQO1 and HO-1 in brain tissues of treated mice [177]. Matrine treatments also were effective in EAE, by which tissue from spinal cord immunohistochemically identified increased protein levels of Nrf2 and HO-1 in treated mice [178]. Last, CDDO-TFEA 
completely suppressed EAE disease in mice, presumably through suppression of inflammatory cytokines, specifically IL-17, and induction of Nrf2-dependent antioxidant gene expression in both CNS and peripheral lymphocytes. In addition, CDDO-TFEA enhanced myelin repair in a lysophosphatidylcholine-induced model of demyelination [176]. Alleviation of neuroinflammatory-induced oxidative stress through activation of Nrf2 and induction of antioxidant is thus an important therapeutic target for prevention of oxidative stress associated with MS, other autoimmune disorders, as well as neuroinflammation associated with other neurodegenerative diseases.

\section{Nrf2 and neuroinflammation}

A pathological hallmark feature of neurodegenerative disease is neuroinflammation, mediated primarily by activated resident innate immune cells, the microglia. When activated, microglia secrete cytotoxic reactive oxygen and nitrogen species, contributing to the deleterious affects on neurons, especially in cases of microglial overactivation and dysregulation. Furthermore, components of dead or damaged neurons also activate microglia (reactive microgliosis) via pattern recognition receptors (e.g., toll-like receptors), resulting in a perpetuating cycle of neuronal cell death $[184,185]$. In an adult human brain, cell densities of microglia are brain-region-dependent and range from 0.5 to $16.6 \%$. Under normal conditions, they reside predominantly in a resting ramified-like morphology in the gray matter, with the highest concentrations found in hippocampus, olfactory telencephalon, basal ganglia, and substantia nigra $[185,186]$. Thus, it comes as no surprise that these brain regions may be more susceptible to reactive microgliosis, as observed in several neurodegenerative diseases, such as AD, PD, HD, and ALS [187].

The most abundant source of reactive species produced by microglia is initiation of the NADPH oxidase (NOX) system generating superoxide anions $\left(\cdot \mathrm{O}_{2}^{-}\right)$. Upon activation by various stimuli, including pathogen-associated molecular patterns (PAMPs), inflammatory cytokines, and/or neurotoxins, the membrane-bound NOX enzyme complex innately promotes microbial killing, as well as changes in morphology, cellular migration, and regulation of proinflammatory gene expression. However, persistent activation of NOX results in peroxidation of lipids and other macromolecules and activation of apoptosis, thus promoting neuronal cell death and degeneration. Similarly, inducible nitric oxide synthase (iNOS) enzyme is induced and its activation results in generation of nitric oxide (NO•), which like $\cdot \mathrm{O}_{2}{ }^{-}$is neurotoxic at continuously high levels. High concentrations of NO• unbalance redox homeostasis, and $\mathrm{NO} \cdot$ can also react with $\bullet^{\mathrm{O}_{2}}{ }^{-}$, resulting in a more toxic reactive species, peroxynitrite $\left(\mathrm{ONNO}^{-}\right)$[188].

Under resting conditions, microglia continuously survey the surrounding environment in search of pathogens, sick cells, or cellular debris, as well as participating in synaptic remodeling and/or maintenance. However, upon activation by hazardous components, microglia become active and in turn secrete proinflammatory mediators such as TNF, interleukin (IL)-1, IL-6, IL-12, and IL-23. This phase of microglia activation is commonly known as the classical proinflammatory phase and termed M1. Following the M1 phase is a longer-lasting anti-inflammatory or alternative phase, M2. Microglia in this phase are activated by anti-inflammatory cytokines, which include IL-4, IL-10, and IL-13. 
Subsequently, these same cytokines are produced, in addition to increased expression of genes involved in wound healing, such as arginase-1 (ARG1), mannose receptors (MMC), found in inflammatory zone 1 (FIZZ1), and chitinase-3-like-1 (Ym1 in rodents). Under normal conditions however, the microglia antioxidant machinery maintains cellular homeostasis and thus microglia are maintained in steady state surveillance mode [185].

The master regulator of the inflammatory responses to brain infections and environmental and cellular damage is the transcription factor NF-kappaB (NF-kB), and it is the redox state of microglia that controls regulatory kinases upstream of NF-kß, as well as NF-kß nuclear levels (recently reviewed in [185]). Microglia function normally when basal levels of OS are managed by antioxidant machinery; however, persistent OS or NS continuously activates the $\mathrm{NF}-\mathrm{k} ß$ signaling pathway, amplifying the proinflammatory function of microglia and thus contributing to microglial overactivation and neurotoxic consequences. Thus, the transcription factor Nrf2, associated with activation of antioxidant genes and redox homeostasis, is the master regulator of microglia fate, protecting microglia from oxidative stress and overactivation of the M1 phenotype. More specifically, activation of Nrf2 drives expression levels of genes involved in (1) OS clearance-SOD3, GPx, and Prx; (2) reducing factor producing enzymes GCLM/C or NADPH (via glucose-6-phosphate dehydrogenase and/or phosphogluconate dehydrogenase); (3) enzymes involved in regeneration of reduced cofactors and proteins, GR, Trx-TrxR, Prx/sulfiredoxin, or redox transporters, xCT; 4) metal chelators, MT1/2 or ferritin; and 5) antioxidant enzymes, HO-1, NQO1, and Trx, and inhibition of the expression of the Trx inhibitor, TXNIP [185].

Several studies have described Nrf2 as a therapeutic target for the alleviation of brain inflammation associated with neurodegeneration and subsequent neuronal protection. In one study, Nrf2-/- mice injected with lipopolysaccharide (LPS), a common inflammogen, were hypersensitive to LPS-induced neuroinflammation in hippocampal tissue. Protein and mRNA for the cellular microglia marker F4/80 were increased in hippocampi of Nrf2-/mice compared with WT mice, as were the inflammatory markers iNOS, IL-6, and TNF-a. Additionally, mice treated with SFN displayed a two- to threefold increase in HO-1, a reduced abundance of microglia, and an attenuated production of these same inflammatory markers in response to LPS [189]. SFN-treated rats subjected to spinal cord injury had significantly increased levels of Nrf2 and GCL and decreased levels of the inflammatory cytokines, IL-1ß and TNF- $\mathrm{a}$, resulting in reduced contusion volume and improved coordination [190].

In a mouse model of PD, inoculation of MPTP in Nrf2-/- mice demonstrated hypersensitivity to OS, with basal ganglia of these mice exhibiting more severe dopaminergic dysfunction when compared with WT littermate controls. Although Cd11bpositive/CD45 highly stained cells, indicative of peripheral macrophage infiltration, were not significantly different between WT and Nrf2-/- mice, the latter mice exhibited more astro- and microgliosis, as determined by increased expression levels of message and protein for GFAP and F4/80 [120]. This validated earlier studies showing increased neuroinflammation associated with astrocytic (GFAP) and microglia (Iba-1) activation in Nrf2-/- mice exposed to MPTP [108]. Furthermore, inflammatory markers for classically activated microglia (M1), COX2, iNOS, IL-6, and TNF-a were also increased, while 
markers for alternatively activated microglia (M2), FIZZ-1, YM-1, arginase-1, and IL-4, were decreased. These results demonstrate a critical role of Nrf2 in the modulation of neuroinflammation secondary to a neurotoxic insult [120].

In hippocampus of mice that were stereotactically injected with an adeno-associated viral vector expressing TAU ${ }^{\mathrm{P} 301 \mathrm{~L}}$ (inducing a mouse model of tauopathy), Nrf2-/- mice showed increased microgliosis and astrogliosis. This was verified by mRNA levels for TNF and IL-6 in hippocampus as well as immunohistochemical staining for Iba- 1 and GFAP. In contrast to WT mice, hippocampal mRNA levels for HO-1 and GCLC did not increase in the Nrf2-/nor did cellular staining for HO-1. This suggests that the Nrf2 signaling pathway was activated by $\mathrm{TAU}^{\mathrm{P} 301 \mathrm{~L}}$-induced pathology in an attempt to modulate the inflammatory response. Based on these observations, as well as studies demonstrating that neuronal expression of the chemokine fractalkine (CX3CL1) modulates TAU-mediated neuroinflammation, these same authors demonstrated that CX3CL1 secreted by injured neurons acted on CX3CR1 receptors (exclusive to microglia), activating the Nrf2-ARE signaling pathway and attenuating $\mathrm{TAU}^{\mathrm{P} 301 \mathrm{~L}}$-induced microgliosis. The latter studies were supported by observations of increased hippocampal microgliosis in CX3CR1-deficient mice in response to TAU ${ }^{\mathrm{P} 301 \mathrm{~L}}$, when compared with WT controls, in addition to the complete loss of the Nrf2-dependent HO-1 immunohistochemical staining in this same cohort. Thus, the release of the chemokine CX3CL1 by injured neurons in turn communicates to microglia via the CX3CR1 receptor, subsequently activating the Nrf2-ARE pathway, to dampen the neuroinflammatory response to injury [191].

In another study using mouse primary neuronal microglia-conditioned media and co-culture experiments, the release of the milk fat globule-EGF factor 8 (MFG-E8) from microglia in response to signals from degenerating neurons exposed to neurotoxic oligomeric amyloid $\beta$ $(\mathrm{OA} ß)$ enhanced the phagocytic activity of microglia. Additionally, microglia treated with MFG-E8 activated the Nrf2 signaling pathway and HO-1. However, in neuronal-microglia co-cultures, the neuroprotection afforded by MFG-E8 was reversed with the HO-1 inhibitor, Tin (IV)-mesoporphyrin IX dichloride (SnMP) treatment, suggesting the importance of HO-1 increase in microglia and subsequent protection of neurons from toxicity [192]. These studies suggest that cellular communication between neurons and microglia and activation of the Nrf2 signaling pathway may be a novel therapeutic approach in the protection of neurons, particularly in neurodegenerative diseases.

\section{NFE2L2 and KEAP1 associated haplotypes and neurodegenerative diseases}

Based on substantial evidence (as discussed in this review) that neurodegenerative effects of OS/NS in diseases such as PD, AD, and ALS can be modulated and/or prevented by upregulation of Nrf2, genomic studies have been undertaken to ascertain if common genetic variations exist in the genes encoding Nrf2 and its repressor protein Keap1, NFE2L2 and $K E A P 1$, thus contributing to the onset or risk of these diseases. Interestingly, based on compilation of publicly available SNPs and other genetic variations, it is estimated that the mutagenic frequency of human NFE2L2 is 1 per $72 \mathrm{bp}$, suggesting that several polymorphisms of this gene may exist [193]. In initial case-controlled studies of patients 
with PD, von Otter et al. identified a protective NFE2L2 haplotype, GAGCAAAA, which included a fully functional variant of the Nrf2 promoter associated with high transcriptional activity in Swedish and Polish material [194]. In the Swedish case study, the GAAAA haplotype allele was associated with an estimated increased age at onset (AAO) of PD of approximately five years per haplotype allele $(p=0.001)$; while in the Polish study, the full protective haplotype, GAGCAAAA, showed a decrease in risk of PD with odds ratios of 0.4 and 0.2 for heterozygous and homozygous carriers, respectively $\left(p=2 \times 10^{-6}\right)$.

Additionally, the Swedish material identified the haplotypes GAGGG and GAAAG in association with increased risk of PD with odds of 2.4 and 3.7 per allele, respectively. Interestingly, the promoter haplotype AGA showed a tendency toward increased risk of PD and full risk with the full promoter haplotype GAGAAGGG (odds ratio of 2.8 per haplotype allele). However, the full haplotype allele, GAGCAAAA, was estimated to delay PD AAO per haplotype allele. No individual SNPs alone, however, significantly affected risk of PD in either Swedish or Polish material. In addition, genetic variations of KEAP1 were also analyzed; however, no associations to AAO or risk of PD were detected [194].

A more recent meta-analysis of genetic associations of Nrf2-encoding NFE2L2 variants in PD using the above data in addition to four new independent European patient-control materials (from Malta, Germany, Italy, and a second Swedish study) also demonstrated an association of haplotype GAGCAAAA (including the fully functional promoter haplotype AGC) with decreased risk (odds ratio (OR) of 0.8 per allele, $p=0.012$ ) and delayed onset of $(+1.1$ years per allele, $p=0.048)$ of PD [195]. These results supported the initial haplotype study that associated variations in the NFE2L2 gene with pathogenesis of PD. The latter study also described four single nucleic acid polymorphisms (SNPs) included in the haplotypes that were associated with AAO of PD (three SNPs that promoted onset included: rs7557529 $\mathrm{G}>\mathrm{A},-1.0$ years per allele, $p=0.042 ;$ rs $35652124 \mathrm{~A}>\mathrm{G},-1.1$ years per allele, $p$ $=0.045 ; \mathrm{rs} 2886161 \mathrm{~A}>\mathrm{G},-1.2$ years per allele, $p=0.021 ;$ and delayed onset SNP: rs $1806649 \mathrm{G}>\mathrm{A},+1.2$ years per allele). Of note, SNP rs35652124 is fully functional and located in the NFE2L2 promoter [195].

In contrast with the above PD studies, genetic analysis of the NFE2L2 promoter did not show variation in a Taiwanese patient controlled PD study. Three SNPs located in the NFE2L2 promoter, rs35652124, rs6706649, and rs6721961, were analyzed independently or with haplotype variants that were associated with PD susceptibility, yet did not correlate with PD susceptibility. The authors concluded that the disparity between the Taiwanese and European studies might be attributed to genomic differences in ethnicity and environmental factors in different geographical regions [196].

Similar studies using AD Swedish case-controlled material did not support NFE2L2 or KEAP1 single SNPs or haplotypes as risk susceptibility genes for AD [197]. However, haplotype analysis of age at $\mathrm{AD}$ onset showed a significant association of haplotype GAAAA with 2 years earlier age at $\mathrm{AD}$ onset $(p=0.013)$, suggesting that common variants of the NFE2L2 gene may affect AD progression thus altering clinically recognized disease onset. Gene variants of NFE2L2 or KEAP1 were not associated with results of mini-mental state examination (MMSE) or CSF biomarker levels of total tau protein and amyloid B 1-42 $\left(\mathrm{A} \beta_{42}\right)$ in these same $\mathrm{AD}$ case-control studies [197]. 
Swedish case-control studies of NFE2L2 and KEAP1 in ALS disease identified one NFE2L2 haplotype (GGGAC) associated with decreased risk of sporadic ALS (OR $=0.62$ per allele, $p=0.015$ ) and one haplotype in KEAPI (CGC) correlated with delayed sporadic ALS onset (+3.4 years per allele, $p=0.015)$. In addition, further stratification of ALS into subgroups identified one subgroup having an NFE2L2-associated haplotype of GAGCAGA, which included three functional promoter SNPs associated with high levels of Nrf2 protein expression, with 4.0 years delayed onset of ALS per allele $(p=0.008)$ [198]. In one other case-controlled study in Italian ALS patients, three NFE2L2 promoter polymorphisms (SNP $-653 \mathrm{~A} / \mathrm{G},-651 \mathrm{G} / \mathrm{A}$, and -617 C/A), no significant differences were observed between ALA cases and controls. The $-653 \mathrm{~A} / \mathrm{G}$ promoter polymorphism was slightly higher in patients than in controls, but it did not attain significance. Furthermore, oxidative stress biomarkers assessed in this same study did not associate with and were independent from the NFE2L2 promoter polymorphisms surveyed [193]. Similar studies have not yet been conducted on HD or MS patients.

\section{Conclusions}

Based on the information provided herein, the Nrf2-ARE pathway is a high-value therapeutic target for neurodegenerative diseases. The existing data are strongest for PD, ALS, and MS, but ongoing experiments in $\mathrm{AD}$ and $\mathrm{HD}$ should provide more insight into how important Nrf2 is in these diseases as well. Numerous cell-based and in silico highthroughput screens have identified novel Nrf2-activating compounds [199-205]. The most promising approach may be to find compounds that noncovalently disrupt the DLG or ETGE motif interactions with Keap1 [206, 207]. Currently, DMF (BG-12) from Biogen Idec has been FDA-approved for treating MS. As discussed above, DMF has also been tested in preclinical models of HD; however, only the CDDO compounds have been tested in preclinical models of the diseases discussed. Reata Pharmaceuticals moved the first CDDO compound (Bardoxolone methyl; CDDO methyl ester) into a Phase III clinical trial for the treatment of chronic kidney disease. Unfortunately, the trial was stopped in 2012 due to a higher rate of cardiovascular events observed in the bardoxolone methyl group compared to placebo [208]. A new CDDO derivative (RTA 408) is already developed and being tested in clinical trials for a variety of non-neurodegenerative diseases, [209-212]. More recently, a clinical trial using RTA 408 was initiated for Friedreich's ataxia, a neurodegenerative condition responsible for cerebellar ataxia due to impaired production of the protein frataxin leading to profound deficiencies in mitochondrial respiration (ClinicalTrials.gov Identifier NCT02255435). Movement of these next generation CDDO compounds into the major neurodegenerative diseases discussed in this review could be an important step forward, based on the preclinical data from earlier generation CDDO compounds.

An interesting new twist to therapeutic approaches targeting this pathway is that one cell type may be better than another at protecting neurons from degeneration. The lack of protection in vivo by overexpression of Nrf2 in neurons or muscle, but protection by overexpression in astrocytes in ALS models, as well as PD models, highlights this concept that not only the pharmacological target, but also the cell type targeted may be relevant when a Nrf2-dependent therapeutic approach is considered. 


\section{Acknowledgments}

This work was supported by Grants R01 ES08089 and R01 ES10042 from the National Institute of Environmental Health Sciences, Grants R01 AG033493 and P50 AG033514 from the National Institute on Aging, and the CHDI Foundation.

\section{References}

[1]. Valko M, Leibfritz D, Moncol J, Cronin MT, Mazur M, Telser J. Free radicals and antioxidants in normal physiological functions and human disease. Int J Biochem Cell Biol. 2007; 39:44-84. [PubMed: 16978905]

[2]. Dasuri K, Zhang L, Keller JN. Oxidative stress, neurodegeneration, and the balance of protein degradation and protein synthesis. Free Radic Biol Med. 2012

[3]. Dexter DT, Carter CJ, Wells FR, Javoy-Agid F, Agid Y, Lees A, Jenner P, Marsden CD. Basal lipid peroxidation in substantia nigra is increased in Parkinson's disease. J Neurochem. 1989; 52:381-9. [PubMed: 2911023]

[4]. Dexter DT, Holley AE, Flitter WD, Slater TF, Wells FR, Daniel SE, Lees AJ, Jenner P, Marsden $\mathrm{CD}$. Increased levels of lipid hydroperoxides in the parkinsonian substantia nigra: an HPLC and ESR study. Mov Disord. 1994; 9:92-7. [PubMed: 8139611]

[5]. Yoritaka A, Hattori N, Uchida K, Tanaka M, Stadtman ER, Mizuno Y. Immunohistochemical detection of 4-hydroxynonenal protein adducts in Parkinson disease. Proc Natl Acad Sci U S A. 1996; 93:2696-701. [PubMed: 8610103]

[6]. Ando Y, Brannstrom T, Uchida K, Nyhlin N, Nasman B, Suhr O, Yamashita T, Olsson T, El Salhy M, Uchino M, Ando M. Histochemical detection of 4-hydroxynonenal protein in Alzheimer amyloid. J Neurol Sci. 1998; 156:172-6. [PubMed: 9588853]

[7]. Markesbery WR, Lovell MA. Four-hydroxynonenal, a product of lipid peroxidation, is increased in the brain in Alzheimer's disease. Neurobiol Aging. 1998; 19:33-6. [PubMed: 9562500]

[8]. Williams TI, Lynn BC, Markesbery WR, Lovell MA. Increased levels of 4-hydroxynonenal and acrolein, neurotoxic markers of lipid peroxidation, in the brain in Mild Cognitive Impairment and early Alzheimer's disease. Neurobiol Aging. 2006; 27:1094-9. [PubMed: 15993986]

[9]. Smith RG, Henry YK, Mattson MP, Appel SH. Presence of 4-hydroxynonenal in cerebrospinal fluid of patients with sporadic amyotrophic lateral sclerosis. Ann Neurol. 1998; 44:696-9. [PubMed: 9778272]

[10]. Simpson EP, Henry YK, Henkel JS, Smith RG, Appel SH. Increased lipid peroxidation in sera of ALS patients: a potential biomarker of disease burden. Neurology. 2004; 62:1758-65. [PubMed: 15159474]

[11]. Montine KS, Kim PJ, Olson SJ, Markesbery WR, Montine TJ. 4-hydroxy-2-nonenal pyrrole adducts in human neurodegenerative disease. J Neuropathol Exp Neurol. 1997; 56:866-71. [PubMed: 9258256]

[12]. Sayre LM, Zelasko DA, Harris PL, Perry G, Salomon RG, Smith MA. 4-Hydroxynonenalderived advanced lipid peroxidation end products are increased in Alzheimer's disease. J Neurochem. 1997; 68:2092-7. [PubMed: 9109537]

[13]. Pedersen WA, Fu W, Keller JN, Markesbery WR, Appel S, Smith RG, Kasarskis E, Mattson MP. Protein modification by the lipid peroxidation product 4-hydroxynonenal in the spinal cords of amyotrophic lateral sclerosis patients. Ann Neurol. 1998; 44:819-24. [PubMed: 9818940]

[14]. Alam ZI, Daniel SE, Lees AJ, Marsden DC, Jenner P, Halliwell B. A generalised increase in protein carbonyls in the brain in Parkinson's but not incidental Lewy body disease. J Neurochem. 1997; 69:1326-9. [PubMed: 9282961]

[15]. Floor E, Wetzel MG. Increased protein oxidation in human substantia nigra pars compacta in comparison with basal ganglia and prefrontal cortex measured with an improved dinitrophenylhydrazine assay. J Neurochem. 1998; 70:268-75. [PubMed: 9422371]

[16]. Aksenov MY, Aksenova MV, Butterfield DA, Geddes JW, Markesbery WR. Protein oxidation in the brain in Alzheimer's disease. Neuroscience. 2001; 103:373-83. [PubMed: 11246152]

Free Radic Biol Med. Author manuscript; available in PMC 2016 November 01. 
[17]. Beal MF. Oxidatively modified proteins in aging and disease. Free Radic Biol Med. 2002; 32:797-803. [PubMed: 11978481]

[18]. Bowling AC, Schulz JB, Brown RH Jr. Beal MF. Superoxide dismutase activity, oxidative damage, and mitochondrial energy metabolism in familial and sporadic amyotrophic lateral sclerosis. J Neurochem. 1993; 61:2322-5. [PubMed: 8245985]

[19]. Hensley K, Hall N, Subramaniam R, Cole P, Harris M, Aksenov M, Aksenova M, Gabbita SP, Wu JF, Carney JM, et al. Brain regional correspondence between Alzheimer's disease histopathology and biomarkers of protein oxidation. J Neurochem. 1995; 65:2146-56. [PubMed: 7595501]

[20]. Lyras L, Cairns NJ, Jenner A, Jenner P, Halliwell B. An assessment of oxidative damage to proteins, lipids, and DNA in brain from patients with Alzheimer's disease. J Neurochem. 1997; 68:2061-9. [PubMed: 9109533]

[21]. Pamplona R, Dalfo E, Ayala V, Bellmunt MJ, Prat J, Ferrer I, Portero-Otin M. Proteins in human brain cortex are modified by oxidation, glycoxidation, and lipoxidation. Effects of Alzheimer disease and identification of lipoxidation targets. J Biol Chem. 2005; 280:21522-30. [PubMed: 15799962]

[22]. Alam ZI, Jenner A, Daniel SE, Lees AJ, Cairns N, Marsden CD, Jenner P, Halliwell B. Oxidative DNA damage in the parkinsonian brain: an apparent selective increase in 8-hydroxyguanine levels in substantia nigra. J Neurochem. 1997; 69:1196-203. [PubMed: 9282943]

[23]. Polidori MC, Mecocci P, Browne SE, Senin U, Beal MF. Oxidative damage to mitochondrial DNA in Huntington's disease parietal cortex. Neurosci Lett. 1999; 272:53-6. [PubMed: 10507541]

[24]. Shibata N, Nagai R, Miyata S, Jono T, Horiuchi S, Hirano A, Kato S, Sasaki S, Asayama K, Kobayashi M. Nonoxidative protein glycation is implicated in familial amyotrophic lateral sclerosis with superoxide dismutase-1 mutation. Acta Neuropathol. 2000; 100:275-84. [PubMed: 10965797]

[25]. Lovell MA, Markesbery WR. Ratio of 8-hydroxyguanine in intact DNA to free 8hydroxyguanine is increased in Alzheimer disease ventricular cerebrospinal fluid. Arch Neurol. 2001; 58:392-6. [PubMed: 11255442]

[26]. Kikuchi A, Takeda A, Onodera H, Kimpara T, Hisanaga K, Sato N, Nunomura A, Castellani RJ, Perry G, Smith MA, Itoyama Y. Systemic increase of oxidative nucleic acid damage in Parkinson's disease and multiple system atrophy. Neurobiol Dis. 2002; 9:244-8. [PubMed: 11895375]

[27]. Ihara Y, Nobukuni K, Takata H, Hayabara T. Oxidative stress and metal content in blood and cerebrospinal fluid of amyotrophic lateral sclerosis patients with and without a $\mathrm{Cu}, \mathrm{Zn}$ superoxide dismutase mutation. Neurol Res. 2005; 27:105-8. [PubMed: 15829169]

[28]. Chen CM, Wu YR, Cheng ML, Liu JL, Lee YM, Lee PW, Soong BW, Chiu DT. Increased oxidative damage and mitochondrial abnormalities in the peripheral blood of Huntington's disease patients. Biochem Biophys Res Commun. 2007; 359:335-40. [PubMed: 17543886]

[29]. Murata T, Ohtsuka C, Terayama Y. Increased mitochondrial oxidative damage and oxidative DNA damage contributes to the neurodegenerative process in sporadic amyotrophic lateral sclerosis. Free Radic Res. 2008; 42:221-5. [PubMed: 18344116]

[30]. Zengi O, Karakas A, Ergun U, Senes M, Inan L, Yucel D. Urinary 8-hydroxy-2'-deoxyguanosine level and plasma paraoxonase 1 activity with Alzheimer's disease. Clin Chem Lab Med. 2012; 50:529-34. [PubMed: 22098435]

[31]. Giasson BI, Duda JE, Murray IV, Chen Q, Souza JM, Hurtig HI, Ischiropoulos H, Trojanowski JQ, Lee VM. Oxidative damage linked to neurodegeneration by selective alpha-synuclein nitration in synucleinopathy lesions. Science. 2000; 290:985-9. [PubMed: 11062131]

[32]. Shimura H, Schlossmacher MG, Hattori N, Frosch MP, Trockenbacher A, Schneider R, Mizuno Y, Kosik KS, Selkoe DJ. Ubiquitination of a new form of alpha-synuclein by parkin from human brain: implications for Parkinson's disease. Science. 2001; 293:263-9. [PubMed: 11431533]

[33]. Fujiwara H, Hasegawa M, Dohmae N, Kawashima A, Masliah E, Goldberg MS, Shen J, Takio K, Iwatsubo T. alpha-Synuclein is phosphorylated in synucleinopathy lesions. Nat Cell Biol. 2002; 4:160-4. [PubMed: 11813001]

Free Radic Biol Med. Author manuscript; available in PMC 2016 November 01. 
[34]. Bramblett GT, Trojanowski JQ, Lee VM. Regions with abundant neurofibrillary pathology in human brain exhibit a selective reduction in levels of binding-competent tau and accumulation of abnormal tau-isoforms (A68 proteins). Lab Invest. 1992; 66:212-22. [PubMed: 1735956]

[35]. Horiguchi T, Uryu K, Giasson BI, Ischiropoulos H, LightFoot R, Bellmann C, Richter-Landsberg C, Lee VM, Trojanowski JQ. Nitration of tau protein is linked to neurodegeneration in tauopathies. Am J Pathol. 2003; 163:1021-31. [PubMed: 12937143]

[36]. Smith MA, Richey Harris PL, Sayre LM, Beckman JS, Perry G. Widespread peroxynitritemediated damage in Alzheimer's disease. J Neurosci. 1997; 17:2653-7. [PubMed: 9092586]

[37]. Hensley K, Maidt ML, Yu Z, Sang H, Markesbery WR, Floyd RA. Electrochemical analysis of protein nitrotyrosine and dityrosine in the Alzheimer brain indicates region-specific accumulation. J Neurosci. 1998; 18:8126-32. [PubMed: 9763459]

[38]. Rushmore TH, Pickett CB. Transcriptional regulation of the rat glutathione S-transferase Ya subunit gene. Characterization of a xenobiotic-responsive element controlling inducible expression by phenolic antioxidants. J Biol Chem. 1990; 265:14648-53. [PubMed: 2387873]

[39]. Rushmore TH, Morton MR, Pickett CB. The antioxidant responsive element. Activation by oxidative stress and identification of the DNA consensus sequence required for functional activity. J Biol Chem. 1991; 266:11632-9. [PubMed: 1646813]

[40]. Itoh K, Wakabayashi N, Katoh Y, Ishii T, Igarashi K, Engel JD, Yamamoto M. Keap1 represses nuclear activation of antioxidant responsive elements by Nrf2 through binding to the aminoterminal Neh2 domain. Genes Dev. 1999; 13:76-86. [PubMed: 9887101]

[41]. Zipper LM, Mulcahy RT. The Keap1 BTB/POZ dimerization function is required to sequester Nrf2 in cytoplasm. J Biol Chem. 2002; 277:36544-52. [PubMed: 12145307]

[42]. Itoh K, Wakabayashi N, Katoh Y, Ishii T, O'Connor T, Yamamoto M. Keap1 regulates both cytoplasmic-nuclear shuttling and degradation of Nrf2 in response to electrophiles. Genes Cells. 2003; 8:379-91. [PubMed: 12653965]

[43]. McMahon M, Itoh K, Yamamoto M, Hayes JD. Keap1-dependent proteasomal degradation of transcription factor Nrf2 contributes to the negative regulation of antioxidant response elementdriven gene expression. J Biol Chem. 2003; 278:21592-600. [PubMed: 12682069]

[44]. Kensler TW, Wakabayashi N, Biswal S. Cell survival responses to environmental stresses via the Keap1-Nrf2-ARE pathway. Annu Rev Pharmacol Toxicol. 2007; 47:89-116. [PubMed: 16968214]

[45]. Sykiotis GP, Bohmann D. Stress-activated cap`n'collar transcription factors in aging and human disease. Sci Signal. 2010; 3:re3. [PubMed: 20215646]

[46]. Zhang DD. Mechanistic studies of the Nrf2-Keap1 signaling pathway. Drug Metab Rev. 2006; 38:769-89. [PubMed: 17145701]

[47]. Dinkova-Kostova AT, Holtzclaw WD, Cole RN, Itoh K, Wakabayashi N, Katoh Y, Yamamoto M, Talalay P. Direct evidence that sulfhydryl groups of Keap1 are the sensors regulating induction of phase 2 enzymes that protect against carcinogens and oxidants. Proc Natl Acad Sci U S A. 2002; 99:11908-13. [PubMed: 12193649]

[48]. Tong KI, Kobayashi A, Katsuoka F, Yamamoto M. Two-site substrate recognition model for the Keap1-Nrf2 system: a hinge and latch mechanism. Biol Chem. 2006; 387:1311-20. [PubMed: 17081101]

[49]. Tong KI, Katoh Y, Kusunoki H, Itoh K, Tanaka T, Yamamoto M. Keap1 recruits Neh2 through binding to ETGE and DLG motifs: characterization of the two-site molecular recognition model. Mol Cell Biol. 2006; 26:2887-900. [PubMed: 16581765]

[50]. Rada P, Rojo AI, Chowdhry S, McMahon M, Hayes JD, Cuadrado A. SCF/\{beta\}-TrCP promotes glycogen synthase kinase 3-dependent degradation of the Nrf2 transcription factor in a Keap1-independent manner. Mol Cell Biol. 2011; 31:1121-33. [PubMed: 21245377]

[51]. Wu T, Zhao F, Gao B, Tan C, Yagishita N, Nakajima T, Wong PK, Chapman E, Fang D, Zhang DD. Hrd1 suppresses Nrf2-mediated cellular protection during liver cirrhosis. Genes Dev. 2014; 28:708-22. [PubMed: 24636985]

[52]. Liu Y, Kern JT, Walker JR, Johnson JA, Schultz PG, Luesch H. A genomic screen for activators of the antioxidant response element. Proc Natl Acad Sci U S A. 2007; 104:5205-10. [PubMed: 17360324] 
[53]. Komatsu M, Kurokawa H, Waguri S, Taguchi K, Kobayashi A, Ichimura Y, Sou YS, Ueno I, Sakamoto A, Tong KI, Kim M, Nishito Y, Iemura SI, Natsume T, Ueno T, Kominami E, Motohashi H, Tanaka K, Yamamoto M. The selective autophagy substrate p62 activates the stress responsive transcription factor Nrf2 through inactivation of Keap1. Nat Cell Biol. 2010

[54]. Hast BE, Goldfarb D, Mulvaney KM, Hast MA, Siesser PF, Yan F, Hayes DN, Major MB. Proteomic analysis of ubiquitin ligase KEAP1 reveals associated proteins that inhibit NRF2 ubiquitination. Cancer Res. 2013; 73:2199-210. [PubMed: 23382044]

[55]. Chen W, Sun Z, Wang XJ, Jiang T, Huang Z, Fang D, Zhang DD. Direct interaction between Nrf2 and p21(Cip1/WAF1) upregulates the Nrf2-mediated antioxidant response. Mol Cell. 2009; 34:663-73. [PubMed: 19560419]

[56]. Camp ND, James RG, Dawson DW, Yan F, Davison JM, Houck SA, Tang X, Zheng N, Major MB, Moon RT. Wilms tumor gene on X chromosome (WTX) inhibits degradation of NRF2 protein through competitive binding to KEAP1 protein. J Biol Chem. 2012; 287:6539-50. [PubMed: 22215675]

[57]. Ma J, Cai H, Wu T, Sobhian B, Huo Y, Alcivar A, Mehta M, Cheung KL, Ganesan S, Kong AN, Zhang DD, Xia B. PALB2 interacts with KEAP1 to promote NRF2 nuclear accumulation and function. Mol Cell Biol. 2012; 32:1506-17. [PubMed: 22331464]

[58]. Alzheimer's Association. 2014 Alzheimer's disease facts and figures. Alzheimers Dement. 2014; 10:e47-92. [PubMed: 24818261]

[59]. Klein WL, Krafft GA, Finch CE. Targeting small Abeta oligomers: the solution to an Alzheimer's disease conundrum? Trends Neurosci. 2001; 24:219-24. [PubMed: 11250006]

[60]. Sandbrink R, Hartmann T, Masters CL, Beyreuther K. Genes contributing to Alzheimer's disease. Mol Psychiatry. 1996; 1:27-40. [PubMed: 9118312]

[61]. Raina AK, Templeton DJ, Deak JC, Perry G, Smith MA. Quinone reductase (NQO1), a sensitive redox indicator, is increased in Alzheimer's disease. Redox Rep. 1999; 4:23-7. [PubMed: 10714272]

[62]. Wang Y, Santa-Cruz K, DeCarli C, Johnson JA. NAD(P)H:quinone oxidoreductase activity is increased in hippocampal pyramidal neurons of patients with Aalzheimer's disease. Neurobiol Aging. 2000; 21:525-31. [PubMed: 10924765]

[63]. SantaCruz KS, Yazlovitskaya E, Collins J, Johnson J, DeCarli C. Regional NAD(P)H:quinone oxidoreductase activity in Alzheimer's disease. Neurobiol Aging. 2004; 25:63-9. [PubMed: 14675732]

[64]. Schipper HM, Cisse S, Stopa EG. Expression of heme oxygenase-1 in the senescent and Alzheimer-diseased brain. Ann Neurol. 1995; 37:758-68. [PubMed: 7778849]

[65]. Schipper HM, Chertkow H, Mehindate K, Frankel D, Melmed C, Bergman H. Evaluation of heme oxygenase-1 as a systemic biological marker of sporadic AD. Neurology. 2000; 54:1297304. [PubMed: 10746601]

[66]. Aksenov MY, Markesbery WR. Changes in thiol content and expression of glutathione redox system genes in the hippocampus and cerebellum in Alzheimer's disease. Neurosci Lett. 2001; 302:141-5. [PubMed: 11290407]

[67]. Tanji K, Maruyama A, Odagiri S, Mori F, Itoh K, Kakita A, Takahashi H, Wakabayashi K. Keap1 is localized in neuronal and glial cytoplasmic inclusions in various neurodegenerative diseases. J Neuropathol Exp Neurol. 2013; 72:18-28. [PubMed: 23242280]

[68]. Ramsey CP, Glass CA, Montgomery MB, Lindl KA, Ritson GP, Chia LA, Hamilton RL, Chu CT, Jordan-Sciutto KL. Expression of Nrf2 in neurodegenerative diseases. J Neuropathol Exp Neurol. 2007; 66:75-85. [PubMed: 17204939]

[69]. Lovell MA, Xie C, Markesbery WR. Decreased glutathione transferase activity in brain and ventricular fluid in Alzheimer's disease. Neurology. 1998; 51:1562-6. [PubMed: 9855502]

[70]. Ansari MA, Scheff SW. Oxidative stress in the progression of Alzheimer disease in the frontal cortex. J Neuropathol Exp Neurol. 2010; 69:155-67. [PubMed: 20084018]

[71]. Saharan S, Mandal PK. The emerging role of glutathione in Alzheimer's disease. J Alzheimers Dis. 2014; 40:519-29. [PubMed: 24496077] 
[72]. Kraft AD, Lee JM, Johnson DA, Kan YW, Johnson JA. Neuronal sensitivity to kainic acid is dependent on the Nrf2-mediated actions of the antioxidant response element. J Neurochem. 2006; 98:1852-65. [PubMed: 16945104]

[73]. Joshi G, Gan KA, Johnson DA, Johnson JA. Increased Alzheimer's disease-like pathology in the APP/ PS1DeltaE9 mouse model lacking Nrf2 through modulation of autophagy. Neurobiol Aging. 2015; 36:664-79. [PubMed: 25316599]

[74]. Kanninen K, Malm TM, Jyrkkanen HK, Goldsteins G, Keksa-Goldsteine V, Tanila H, Yamamoto M, Yla-Herttuala S, Levonen AL, Koistinaho J. Nuclear factor erythroid 2-related factor 2 protects against beta amyloid. Mol Cell Neurosci. 2008; 39:302-13. [PubMed: 18706502]

[75]. Torres-Lista V, Parrado-Fernandez C, Alvarez-Monton I, Frontinan-Rubio J, Duran-Prado M, Peinado JR, Johansson B, Alcain FJ, Gimenez-Llort L. Neophobia, NQO1 and SIRT1 as premorbid and prodromal indicators of AD in 3xTg-AD mice. Behav Brain Res. 2014; 271:140 6. [PubMed: 24837743]

[76]. Mota SI, Costa RO, Ferreira IL, Santana I, Caldeira GL, Padovano C, Fonseca AC, Baldeiras I, Cunha C, Letra L, Oliveira CR, Pereira CM, Rego AC. Oxidative stress involving changes in Nrf2 and ER stress in early stages of Alzheimer's disease. Biochim Biophys Acta. 2015

[77]. Jain A, Lamark T, Sjottem E, Larsen KB, Awuh JA, Overvatn A, McMahon M, Hayes JD, Johansen T. p62/SQSTM1 is a target gene for transcription factor NRF2 and creates a positive feedback loop by inducing antioxidant response element-driven gene transcription. J Biol Chem. 2010; 285:22576-91. [PubMed: 20452972]

[78]. Riley BE, Kaiser SE, Kopito RR. Autophagy inhibition engages Nrf2-p62 Ub-associated signaling. Autophagy. 2010; 7:338-40. [PubMed: 21252622]

[79]. Fujita K, Maeda D, Xiao Q, Srinivasula SM. Nrf2-mediated induction of p62 controls Toll-like receptor-4-driven aggresome-like induced structure formation and autophagic degradation. Proc Natl Acad Sci U S A. 2011; 108:1427-32. [PubMed: 21220332]

[80]. Jo C, Gundemir S, Pritchard S, Jin YN, Rahman I, Johnson GV. Nrf2 reduces levels of phosphorylated tau protein by inducing autophagy adaptor protein NDP52. Nat Commun. 2014; 5:3496. [PubMed: 24667209]

[81]. Farr SA, Ripley JL, Sultana R, Zhang Z, Niehoff ML, Platt TL, Murphy MP, Morley JE, Kumar V, Butterfield DA. Antisense oligonucleotide against GSK-3beta in brain of SAMP8 mice improves learning and memory and decreases oxidative stress: Involvement of transcription factor Nrf2 and implications for Alzheimer disease. Free Radic Biol Med. 2014; 67:387-95. [PubMed: 24355211]

[82]. Kanninen K, Heikkinen R, Malm T, Rolova T, Kuhmonen S, Leinonen H, Yla-Herttuala S, Tanila H, Levonen AL, Koistinaho M, Koistinaho J. Intrahippocampal injection of a lentiviral vector expressing Nrf2 improves spatial learning in a mouse model of Alzheimer's disease. Proc Natl Acad Sci U S A. 2009; 106:16505-10. [PubMed: 19805328]

[83]. Shih AY, Johnson DA, Wong G, Kraft AD, Jiang L, Erb H, Johnson JA, Murphy TH. Coordinate regulation of glutathione biosynthesis and release by Nrf2-expressing glia potently protects neurons from oxidative stress. J Neurosci. 2003; 23:3394-406. [PubMed: 12716947]

[84]. Kraft AD, Johnson DA, Johnson JA. Nuclear factor E2-related factor 2-dependent antioxidant response element activation by tert-butylhydroquinone and sulforaphane occurring preferentially in astrocytes conditions neurons against oxidative insult. J Neurosci. 2004; 24:1101-12. [PubMed: 14762128]

[85]. Vargas MR, Johnson DA, Sirkis DW, Messing A, Johnson JA. Nrf2 activation in astrocytes protects against neurodegeneration in mouse models of familial amyotrophic lateral sclerosis. $\mathrm{J}$ Neurosci. 2008; 28:13574-81. [PubMed: 19074031]

[86]. Dumont M, Wille E, Calingasan NY, Tampellini D, Williams C, Gouras GK, Liby K, Sporn M, Nathan C, Flint Beal M, Lin MT. Triterpenoid CDDO-methylamide improves memory and decreases amyloid plaques in a transgenic mouse model of Alzheimer's disease. J Neurochem. 2009; 109:502-12. [PubMed: 19200343]

[87]. Zhou Y, Xie N, Li L, Zou Y, Zhang X, Dong M. Puerarin alleviates cognitive impairment and oxidative stress in APP/PS1 transgenic mice. Int J Neuropsychopharmacol. 2014; 17:635-44. [PubMed: 24345484] 
[88]. Leiros M, Alonso E, Rateb ME, Houssen WE, Ebel R, Jaspars M, Alfonso A, Botana LM. Gracilins: Spongionella-derived promising compounds for Alzheimer disease. Neuropharmacology. 2015; 93:285-93. [PubMed: 25724081]

[89]. Jeon S, Hur J, Jeong HJ, Koo BS, Pak SC. SuHeXiang Wan essential oil alleviates amyloid beta induced memory impairment through inhibition of tau protein phosphorylation in mice. Am J Chin Med. 2011; 39:917-32. [PubMed: 21905282]

[90]. Kim HV, Kim HY, Ehrlich HY, Choi SY, Kim DJ, Kim Y. Amelioration of Alzheimer's disease by neuroprotective effect of sulforaphane in animal model. Amyloid. 2013; 20:7-12. [PubMed: 23253046]

[91]. Zhang R, Miao QW, Zhu CX, Zhao Y, Liu L, Yang J, An L. Sulforaphane Ameliorates Neurobehavioral Deficits and Protects the Brain From Amyloid beta Deposits and Peroxidation in Mice With Alzheimer-Like Lesions. Am J Alzheimers Dis Other Demen. 2015; 30:183-91. [PubMed: 25024455]

[92]. Xie G, Tian W, Wei T, Liu F. The neuroprotective effects of beta-hydroxybutyrate on Abetainjected rat hippocampus in vivo and in Abeta-treated PC-12 cells in vitro. Free Radic Res. 2015; 49:139-50. [PubMed: 25410532]

[93]. Yu L, Wang S, Chen X, Yang H, Li X, Xu Y, Zhu X. Orientin alleviates cognitive deficits and oxidative stress in Abeta1-42-induced mouse model of Alzheimer's disease. Life Sci. 2015; 121:104-9. [PubMed: 25497709]

[94]. Chen C, Li X, Gao P, Tu Y, Zhao M, Li J, Zhang S, Liang H. Baicalin attenuates alzheimer-like pathological changes and memory deficits induced by amyloid beta1-42 protein. Metab Brain Dis. 2015; 30:537-44. [PubMed: 25108596]

[95]. Beal MF. Therapeutic approaches to mitochondrial dysfunction in Parkinson's disease. Parkinsonism Relat Disord. 2009; 15(Suppl 3):S189-94. [PubMed: 20082988]

[96]. Spillantini MG, Schmidt ML, Lee VM, Trojanowski JQ, Jakes R, Goedert M. Alpha-synuclein in Lewy bodies. Nature. 1997; 388:839-40. [PubMed: 9278044]

[97]. Irizarry MC, Growdon W, Gomez-Isla T, Newell K, George JM, Clayton DF, Hyman BT. Nigral and cortical Lewy bodies and dystrophic nigral neurites in Parkinson's disease and cortical Lewy body disease contain alpha-synuclein immunoreactivity. J Neuropathol Exp Neurol. 1998; 57:334-7. [PubMed: 9600226]

[98]. Spillantini MG, Crowther RA, Jakes R, Hasegawa M, Goedert M. alpha-Synuclein in filamentous inclusions of Lewy bodies from Parkinson's disease and dementia with lewy bodies. Proc Natl Acad Sci U S A. 1998; 95:6469-73. [PubMed: 9600990]

[99]. Samii A, Nutt JG, Ransom BR. Parkinson's disease. Lancet. 2004; 363:1783-93. [PubMed: 15172778]

[100]. Lesage S, Brice A. Parkinson's disease: from monogenic forms to genetic susceptibility factors. Hum Mol Genet. 2009; 18:R48-59. [PubMed: 19297401]

[101]. van Muiswinkel FL, de Vos RA, Bol JG, Andringa G, Jansen Steur EN, Ross D, Siegel D, Drukarch B. Expression of NAD(P)H:quinone oxidoreductase in the normal and Parkinsonian substantia nigra. Neurobiol Aging. 2004; 25:1253-62. [PubMed: 15312971]

[102]. Castellani R, Smith MA, Richey PL, Perry G. Glycoxidation and oxidative stress in Parkinson disease and diffuse Lewy body disease. Brain Res. 1996; 737:195-200. [PubMed: 8930366]

[103]. Schipper HM, Liberman A, Stopa EG. Neural heme oxygenase-1 expression in idiopathic Parkinson's disease. Exp Neurol. 1998; 150:60-8. [PubMed: 9514830]

[104]. Basso M, Giraudo S, Corpillo D, Bergamasco B, Lopiano L, Fasano M. Proteome analysis of human substantia nigra in Parkinson's disease. Proteomics. 2004; 4:3943-52. [PubMed: 15526345]

[105]. Perry TL, Yong VW. Idiopathic Parkinson's disease, progressive supranuclear palsy and glutathione metabolism in the substantia nigra of patients. Neurosci Lett. 1986; 67:269-74. [PubMed: 3737015]

[106]. Zeevalk GD, Razmpour R, Bernard LP. Glutathione and Parkinson's disease: is this the elephant in the room? Biomed Pharmacother. 2008; 62:236-49. [PubMed: 18400456]

[107]. Imaizumi Y, Okada Y, Akamatsu W, Koike M, Kuzumaki N, Hayakawa H, Nihira T, Kobayashi T, Ohyama M, Sato S, Takanashi M, Funayama M, Hirayama A, Soga T, Hishiki T, 
Suematsu M, Yagi T, Ito D, Kosakai A, Hayashi K, Shouji M, Nakanishi A, Suzuki N, Mizuno Y, Mizushima N, Amagai M, Uchiyama Y, Mochizuki H, Hattori N, Okano H. Mitochondrial dysfunction associated with increased oxidative stress and alpha-synuclein accumulation in PARK2 iPSC-derived neurons and postmortem brain tissue. Mol Brain. 2012; 5:35. [PubMed: 23039195]

[108]. Chen PC, Vargas MR, Pani AK, Smeyne RJ, Johnson DA, Kan YW, Johnson JA. Nrf2mediated neuroprotection in the MPTP mouse model of Parkinson's disease: Critical role for the astrocyte. Proc Natl Acad Sci U S A. 2009; 106:2933-8. [PubMed: 19196989]

[109]. Johnson DA, Andrews GK, Xu W, Johnson JA. Activation of the antioxidant response element in primary cortical neuronal cultures derived from transgenic reporter mice. J Neurochem. 2002; 81:1233-41. [PubMed: 12068071]

[110]. Minelli A, Conte C, Cacciatore I, Cornacchia C, Pinnen F. Molecular mechanism underlying the cerebral effect of Gly-Pro-Glu tripeptide bound to L: -dopa in a Parkinson's animal model. Amino Acids. 2012

[111]. Innamorato NG, Jazwa A, Rojo AI, Garcia C, Fernandez-Ruiz J, Grochot-Przeczek A, Stachurska A, Jozkowicz A, Dulak J, Cuadrado A. Different susceptibility to the Parkinson's toxin MPTP in mice lacking the redox master regulator Nrf2 or its target gene heme oxygenase-1. PLoS One. 2010; 5:e11838. [PubMed: 20676377]

[112]. Lu C, Zhang J, Shi X, Miao S, Bi L, Zhang S, Yang Q, Zhou X, Zhang M, Xie Y, Miao Q, Wang S. Neuroprotective effects of tetramethylpyrazine against dopaminergic neuron injury in a rat model of Parkinson's disease induced by MPTP. Int J Biol Sci. 2014; 10:350-7. [PubMed: 24719552]

[113]. Tsou YH, Shih CT, Ching CH, Huang JY, Jen CJ, Yu L, Kuo YM, Wu FS, Chuang JI. Treadmill exercise activates Nrf2 antioxidant system to protect the nigrostriatal dopaminergic neurons from MPP+ toxicity. Exp Neurol. 2015; 263:50-62. [PubMed: 25286336]

[114]. Jakel RJ, Kern JT, Johnson DA, Johnson JA. Induction of the protective antioxidant response element pathway by 6-hydroxydopamine in vivo and in vitro. Toxicol Sci. 2005; 87:176-86. [PubMed: 15976186]

[115]. Li R, Liang T, Xu L, Zheng N, Zhang K, Duan X. Puerarin attenuates neuronal degeneration in the substantia nigra of 6-OHDA-lesioned rats through regulating BDNF expression and activating the Nrf2/ARE signaling pathway. Brain Res. 2013; 1523:1-9. [PubMed: 23747813]

[116]. Gan L, Vargas MR, Johnson DA, Johnson JA. Astrocyte-specific overexpression of Nrf2 delays motor pathology and synuclein aggregation throughout the CNS in the alpha-synuclein mutant (A53T) mouse model. J Neurosci. 2012; 32:17775-87. [PubMed: 23223297]

[117]. Beraud D, Hathaway HA, Trecki J, Chasovskikh S, Johnson DA, Johnson JA, Federoff HJ, Shimoji M, Mhyre TR, Maguire-Zeiss KA. Microglial activation and antioxidant responses induced by the Parkinson's disease protein alpha-synuclein. J Neuroimmune Pharmacol. 2013; 8:94-117. [PubMed: 23054368]

[118]. Burton NC, Kensler TW, Guilarte TR. In vivo modulation of the Parkinsonian phenotype by Nrf2. Neurotoxicology. 2006; 27:1094-100. [PubMed: 16959318]

[119]. Jakel RJ, Townsend JA, Kraft AD, Johnson JA. Nrf2-mediated protection against 6hydroxydopamine. Brain Res. 2007; 1144:192-201. [PubMed: 17336276]

[120]. Rojo AI, Innamorato NG, Martin-Moreno AM, De Ceballos ML, Yamamoto M, Cuadrado A. Nrf2 regulates microglial dynamics and neuroinflammation in experimental Parkinson's disease. Glia. 2010; 58:588-98. [PubMed: 19908287]

[121]. Jazwa A, Rojo AI, Innamorato NG, Hesse M, Fernandez-Ruiz J, Cuadrado A. Pharmacological targeting of the transcription factor Nrf2 at the basal ganglia provides disease modifying therapy for experimental parkinsonism. Antioxid Redox Signal. 2011; 14:2347-60. [PubMed: 21254817]

[122]. Kaidery NA, Banerjee R, Yang L, Smirnova NA, Hushpulian DM, Liby KT, Williams CR, Yamamoto M, Kensler TW, Ratan RR, Sporn MB, Beal MF, Gazaryan IG, Thomas B. Targeting Nrf2-mediated gene transcription by extremely potent synthetic triterpenoids attenuate dopaminergic neurotoxicity in the MPTP mouse model of Parkinson's disease. Antioxid Redox Signal. 2013; 18:139-57. [PubMed: 22746536]

Free Radic Biol Med. Author manuscript; available in PMC 2016 November 01. 
[123]. Lastres-Becker I, Ulusoy A, Innamorato NG, Sahin G, Rabano A, Kirik D, Cuadrado A. alphaSynuclein expression and Nrf2 deficiency cooperate to aggravate protein aggregation, neuronal death and inflammation in early-stage Parkinson's disease. Hum Mol Genet. 2012; 21:3173-92. [PubMed: 22513881]

[124]. Rowland LP, Shneider NA. Amyotrophic lateral sclerosis. N Engl J Med. 2001; 344:1688-700. [PubMed: 11386269]

[125]. Murayama S, Ookawa Y, Mori H, Nakano I, Ihara Y, Kuzuhara S, Tomonaga M. Immunocytochemical and ultrastructural study of Lewy body-like hyaline inclusions in familial amyotrophic lateral sclerosis. Acta Neuropathol. 1989; 78:143-52. [PubMed: 2473594]

[126]. Mizuno Y, Amari M, Takatama M, Aizawa H, Mihara B, Okamoto K. Immunoreactivities of p62, an ubiqutin-binding protein, in the spinal anterior horn cells of patients with amyotrophic lateral sclerosis. J Neurol Sci. 2006; 249:13-8. [PubMed: 16820172]

[127]. Tan CF, Eguchi H, Tagawa A, Onodera O, Iwasaki T, Tsujino A, Nishizawa M, Kakita A, Takahashi H. TDP-43 immunoreactivity in neuronal inclusions in familial amyotrophic lateral sclerosis with or without SOD1 gene mutation. Acta Neuropathol. 2007; 113:535-42. [PubMed: 17333220]

[128]. Vance C, Rogelj B, Hortobagyi T, De Vos KJ, Nishimura AL, Sreedharan J, Hu X, Smith B, Ruddy D, Wright P, Ganesalingam J, Williams KL, Tripathi V, Al-Saraj S, Al-Chalabi A, Leigh PN, Blair IP, Nicholson G, de Belleroche J, Gallo JM, Miller CC, Shaw CE. Mutations in FUS, an RNA processing protein, cause familial amyotrophic lateral sclerosis type 6. Science. 2009; 323:1208-11. [PubMed: 19251628]

[129]. Rosen DR, Siddique T, Patterson D, Figlewicz DA, Sapp P, Hentati A, Donaldson D, Goto J, O'Regan JP, Deng HX, et al. Mutations in $\mathrm{Cu} / \mathrm{Zn}$ superoxide dismutase gene are associated with familial amyotrophic lateral sclerosis. Nature. 1993; 362:59-62. [PubMed: 8446170]

[130]. Gurney ME, Pu H, Chiu AY, Dal Canto MC, Polchow CY, Alexander DD, Caliendo J, Hentati A, Kwon YW, Deng HX, et al. Motor neuron degeneration in mice that express a human $\mathrm{Cu}, \mathrm{Zn}$ superoxide dismutase mutation. Science. 1994; 264:1772-5. [PubMed: 8209258]

[131]. Howland DS, Liu J, She Y, Goad B, Maragakis NJ, Kim B, Erickson J, Kulik J, DeVito L, Psaltis G, DeGennaro LJ, Cleveland DW, Rothstein JD. Focal loss of the glutamate transporter EAAT2 in a transgenic rat model of SOD1 mutant-mediated amyotrophic lateral sclerosis (ALS). Proc Natl Acad Sci U S A. 2002; 99:1604-9. [PubMed: 11818550]

[132]. Clement AM, Nguyen MD, Roberts EA, Garcia ML, Boillee S, Rule M, McMahon AP, Doucette W, Siwek D, Ferrante RJ, Brown RH Jr. Julien JP, Goldstein LS, Cleveland DW. Wildtype nonneuronal cells extend survival of SOD1 mutant motor neurons in ALS mice. Science. 2003; 302:113-7. [PubMed: 14526083]

[133]. Marangi G, Traynor BJ. Genetic causes of amyotrophic lateral sclerosis: New genetic analysis methodologies entailing new opportunities and challenges. Brain Res. 2015; 1607:75-93. [PubMed: 25316630]

[134]. Fecto F, Yan J, Vemula SP, Liu E, Yang Y, Chen W, Zheng JG, Shi Y, Siddique N, Arrat H, Donkervoort S, Ajroud-Driss S, Sufit RL, Heller SL, Deng HX, Siddique T. SQSTM1 mutations in familial and sporadic amyotrophic lateral sclerosis. Arch Neurol. 2011; 68:1440-6. [PubMed: 22084127]

[135]. Sarlette A, Krampfl K, Grothe C, Neuhoff N, Dengler R, Petri S. Nuclear erythroid 2-related factor 2-antioxidative response element signaling pathway in motor cortex and spinal cord in amyotrophic lateral sclerosis. J Neuropathol Exp Neurol. 2008; 67:1055-62. [PubMed: 18957896]

[136]. Vargas MR, Pehar M, Cassina P, Martinez-Palma L, Thompson JA, Beckman JS, Barbeito L. Fibroblast growth factor-1 induces heme oxygenase-1 via nuclear factor erythroid 2-related factor 2 (Nrf2) in spinal cord astrocytes: consequences for motor neuron survival. J Biol Chem. 2005; 280:25571-9. [PubMed: 15870071]

[137]. Vargas MR, Pehar M, Cassina P, Beckman JS, Barbeito L. Increased glutathione biosynthesis by Nrf2 activation in astrocytes prevents p75NTR-dependent motor neuron apoptosis. $\mathbf{J}$ Neurochem. 2006; 97:687-96. [PubMed: 16524372]

[138]. Pehar M, Vargas MR, Robinson KM, Cassina P, Diaz-Amarilla PJ, Hagen TM, Radi R, Barbeito L, Beckman JS. Mitochondrial superoxide production and nuclear factor erythroid 2- 
related factor 2 activation in $\mathrm{p} 75$ neurotrophin receptor-induced motor neuron apoptosis. $\mathbf{J}$ Neurosci. 2007; 27:7777-85. [PubMed: 17634371]

[139]. Mimoto T, Miyazaki K, Morimoto N, Kurata T, Satoh K, Ikeda Y, Abe K. Impaired antioxydative Keap1/Nrf2 system and the downstream stress protein responses in the motor neuron of ALS model mice. Brain Res. 2012; 1446:109-18. [PubMed: 22353756]

[140]. Guo Y, Zhang Y, Wen D, Duan W, An T, Shi P, Wang J, Li Z, Chen X, Li C. The modest impact of transcription factor Nrf2 on the course of disease in an ALS animal model. Lab Invest. 2013; 93:825-33. [PubMed: 23711824]

[141]. Kraft AD, Resch JM, Johnson DA, Johnson JA. Activation of the Nrf2-ARE pathway in muscle and spinal cord during ALS-like pathology in mice expressing mutant SOD1. Exp Neurol. 2007; 207:107-17. [PubMed: 17631292]

[142]. Vargas MR, Burton NC, Kutzke J, Gan L, Johnson DA, Schafer M, Werner S, Johnson JA. Absence of Nrf2 or its selective overexpression in neurons and muscle does not affect survival in ALS-linked mutant hSOD1 mouse models. PLoS One. 2013; 8:e56625. [PubMed: 23418589]

[143]. Nanou A, Higginbottom A, Valori CF, Wyles M, Ning K, Shaw P, Azzouz M. Viral delivery of antioxidant genes as a therapeutic strategy in experimental models of amyotrophic lateral sclerosis. Mol Ther. 2013; 21:1486-96. [PubMed: 23732987]

[144]. Neymotin A, Calingasan NY, Wille E, Naseri N, Petri S, Damiano M, Liby KT, Risingsong R, Sporn M, Beal MF, Kiaei M. Neuroprotective effect of Nrf2/ARE activators, CDDO ethylamide and CDDO trifluoroethylamide, in a mouse model of amyotrophic lateral sclerosis. Free Radic Biol Med. 2011; 51:88-96. [PubMed: 21457778]

[145]. Feng X, Peng Y, Liu M, Cui L. DL-3-n-butylphthalide extends survival by attenuating glial activation in a mouse model of amyotrophic lateral sclerosis. Neuropharmacology. 2012; 62:1004-10. [PubMed: 22056419]

[146]. Mead RJ, Higginbottom A, Allen SP, Kirby J, Bennett E, Barber SC, Heath PR, Coluccia A, Patel N, Gardner I, Brancale A, Grierson AJ, Shaw PJ. S[+] Apomorphine is a CNS penetrating activator of the Nrf2-ARE pathway with activity in mouse and patient fibroblast models of amyotrophic lateral sclerosis. Free Radic Biol Med. 2013; 61:438-52. [PubMed: 23608463]

[147]. Kanno T, Tanaka K, Yanagisawa Y, Yasutake K, Hadano S, Yoshii F, Hirayama N, Ikeda JE. A novel small molecule, N-(4-(2-pyridyl)(1,3-thiazol-2-yl))-2-(2,4,6-trimethylphenoxy) acetamide, selectively protects against oxidative stress-induced cell death by activating the Nrf2-ARE pathway: therapeutic implications for ALS. Free Radic Biol Med. 2012; 53:2028-42. [PubMed: 23000247]

[148]. Tanaka K, Kanno T, Yanagisawa Y, Yasutake K, Inoue S, Hirayama N, Ikeda JE. A novel acylaminoimidazole derivative, WN1316, alleviates disease progression via suppression of glial inflammation in ALS mouse model. PLoS One. 2014; 9:e87728. [PubMed: 24498180]

[149]. The Huntington's Disease Collaborative Research Group. A novel gene containing a trinucleotide repeat that is expanded and unstable on Huntington's disease chromosomes. Cell. 1993; 72:971-83. [PubMed: 8458085]

[150]. Bates G. Huntingtin aggregation and toxicity in Huntington's disease. Lancet. 2003; 361:16424. [PubMed: 12747895]

[151]. Browne SE, Beal MF. Oxidative damage in Huntington's disease pathogenesis. Antioxid Redox Signal. 2006; 8:2061-73. [PubMed: 17034350]

[152]. Johri A, Chandra A, Beal MF. PGC-1alpha, mitochondrial dysfunction, and Huntington's disease. Free Radic Biol Med. 2013; 62:37-46. [PubMed: 23602910]

[153]. Reddy PH. Increased mitochondrial fission and neuronal dysfunction in Huntington's disease: implications for molecular inhibitors of excessive mitochondrial fission. Drug Discov Today. 2014; 19:951-5. [PubMed: 24681059]

[154]. Browne SE, Ferrante RJ, Beal MF. Oxidative stress in Huntington's disease. Brain Pathol. 1999; 9:147-63. [PubMed: 9989457]

[155]. Beal MF, Brouillet E, Jenkins B, Henshaw R, Rosen B, Hyman BT. Age-dependent striatal excitotoxic lesions produced by the endogenous mitochondrial inhibitor malonate. J Neurochem. 1993; 61:1147-50. [PubMed: 7689641] 
[156]. Borlongan CV, Koutouzis TK, Sanberg PR. 3-Nitropropionic acid animal model and Huntington's disease. Neurosci Biobehav Rev. 1997; 21:289-93. [PubMed: 9168265]

[157]. Calkins MJ, Jakel RJ, Johnson DA, Chan K, Kan YW, Johnson JA. Protection from mitochondrial complex II inhibition in vitro and in vivo by Nrf2-mediated transcription. Proc Natl Acad Sci U S A. 2005; 102:244-9. [PubMed: 15611470]

[158]. Calkins MJ, Vargas MR, Johnson DA, Johnson JA. Astrocyte-specific overexpression of Nrf2 protects striatal neurons from mitochondrial complex II inhibition. Toxicol Sci. 2010; 115:55768. [PubMed: 20211941]

[159]. Gao Y, Chu SF, Li JP, Zhang Z, Yan JQ, Wen ZL, Xia CY, Mou Z, Wang ZZ, He WB, Guo XF, Wei GN, Chen NH. Protopanaxtriol protects against 3-nitropropionic acid-induced oxidative stress in a rat model of Huntington's disease. Acta Pharmacol Sin. 2015; 36:311-22. [PubMed: 25640478]

[160]. Gopinath K, Sudhandiran G. Naringin modulates oxidative stress and inflammation in 3nitropropionic acid-induced neurodegeneration through the activation of nuclear factor-erythroid 2-related factor-2 signalling pathway. Neuroscience. 2012; 227:134-43. [PubMed: 22871521]

[161]. Frederick NM, Bertho J, Patel KK, Petr GT, Bakradze E, Smith SB, Rosenberg PA. Dysregulation of system xc(-) expression induced by mutant huntingtin in a striatal neuronal cell line and in R6/2 mice. Neurochem Int. 2014; 76:59-69. [PubMed: 25004085]

[162]. Shih AY, Imbeault S, Barakauskas V, Erb H, Jiang L, Li P, Murphy TH. Induction of the Nrf2driven antioxidant response confers neuroprotection during mitochondrial stress in vivo. J Biol Chem. 2005; 280:22925-36. [PubMed: 15840590]

[163]. Calkins MJ, Townsend JA, Johnson DA, Johnson JA. Cystamine protects from 3-nitropropionic acid lesioning via induction of nf-e2 related factor 2 mediated transcription. Exp Neurol. 2010; 224:307-17. [PubMed: 20406637]

[164]. Yang L, Calingasan NY, Thomas B, Chaturvedi RK, Kiaei M, Wille EJ, Liby KT, Williams C, Royce D, Risingsong R, Musiek ES, Morrow JD, Sporn M, Beal MF. Neuroprotective effects of the triterpenoid, CDDO methyl amide, a potent inducer of Nrf2-mediated transcription. PLoS One. 2009; 4:e5757. [PubMed: 19484125]

[165]. Stack C, Ho D, Wille E, Calingasan NY, Williams C, Liby K, Sporn M, Dumont M, Beal MF. Triterpenoids CDDO-ethyl amide and CDDO-trifluoroethyl amide improve the behavioral phenotype and brain pathology in a transgenic mouse model of Huntington's disease. Free Radic Biol Med. 2010; 49:147-58. [PubMed: 20338236]

[166]. Ellrichmann G, Petrasch-Parwez E, Lee DH, Reick C, Arning L, Saft C, Gold R, Linker RA. Efficacy of fumaric acid esters in the R6/2 and YAC128 models of Huntington's disease. PLoS One. 2011; 6:e16172. [PubMed: 21297955]

[167]. National Multiple Sclerosis Society. [Accessed 15 Feb] Who Gets MS?. 2015. http:// www.nationalmssociety.org/What-is-MS/Who-Gets-MS

[168]. Dhib-Jalbut S. Pathogenesis of myelin/oligodendrocyte damage in multiple sclerosis. Neurology. 2007; 68:S13-21. discussion S43-54. [PubMed: 17548563]

[169]. Hofstetter H, Gold R, Hartung HP. Th17 Cells in MS and Experimental Autoimmune Encephalomyelitis. Int MS J. 2009; 16:12-8. [PubMed: 19413921]

[170]. Chiurchiu V. Novel targets in multiple sclerosis: to oxidative stress and beyond. Curr Top Med Chem. 2014; 14:2590-9. [PubMed: 25478879]

[171]. van Horssen J, Schreibelt G, Bo L, Montagne L, Drukarch B, van Muiswinkel FL, de Vries HE. $\mathrm{NAD}(\mathrm{P}) \mathrm{H}$ :quinone oxidoreductase 1 expression in multiple sclerosis lesions. Free Radic Biol Med. 2006; 41:311-7. [PubMed: 16814112]

[172]. van Horssen J, Schreibelt G, Drexhage J, Hazes T, Dijkstra CD, van der Valk P, de Vries HE. Severe oxidative damage in multiple sclerosis lesions coincides with enhanced antioxidant enzyme expression. Free Radic Biol Med. 2008; 45:1729-37. [PubMed: 18930811]

[173]. van Horssen J, Drexhage JA, Flor T, Gerritsen W, van der Valk P, de Vries HE. Nrf2 and DJ1 are consistently upregulated in inflammatory multiple sclerosis lesions. Free Radic Biol Med. 2010; 49:1283-9. [PubMed: 20673799]

Free Radic Biol Med. Author manuscript; available in PMC 2016 November 01. 
[174]. Johnson DA, Amirahmadi S, Ward C, Fabry Z, Johnson JA. The absence of the pro-antioxidant transcription factor Nrf2 exacerbates experimental autoimmune encephalomyelitis. Toxicol Sci. 2010; 114:237-46. [PubMed: 19910389]

[175]. Linker RA, Lee DH, Ryan S, van Dam AM, Conrad R, Bista P, Zeng W, Hronowsky X, Buko A, Chollate S, Ellrichmann G, Bruck W, Dawson K, Goelz S, Wiese S, Scannevin RH, Lukashev M, Gold R. Fumaric acid esters exert neuroprotective effects in neuroinflammation via activation of the Nrf2 antioxidant pathway. Brain. 2011; 134:678-92. [PubMed: 21354971]

[176]. Pareek TK, Belkadi A, Kesavapany S, Zaremba A, Loh SL, Bai L, Cohen ML, Meyer C, Liby KT, Miller RH, Sporn MB, Letterio JJ. Triterpenoid modulation of IL-17 and Nrf-2 expression ameliorates neuroinflammation and promotes remyelination in autoimmune encephalomyelitis. Sci Rep. 2011; 1:201. [PubMed: 22355716]

[177]. Li B, Cui W, Liu J, Li R, Liu Q, Xie XH, Ge XL, Zhang J, Song XJ, Wang Y, Guo L. Sulforaphane ameliorates the development of experimental autoimmune encephalomyelitis by antagonizing oxidative stress and Th17-related inflammation in mice. Exp Neurol. 2013; 250:239-49. [PubMed: 24120440]

[178]. Liu N, Kan QC, Zhang XJ, Xv YM, Zhang S, Zhang GX, Zhu L. Upregulation of immunomodulatory molecules by matrine treatment in experimental autoimmune encephalomyelitis. Exp Mol Pathol. 2014; 97:470-6. [PubMed: 25303900]

[179]. Schilling S, Goelz S, Linker R, Luehder F, Gold R. Fumaric acid esters are effective in chronic experimental autoimmune encephalomyelitis and suppress macrophage infiltration. Clin Exp Immunol. 2006; 145:101-7. [PubMed: 16792679]

[180]. Murphy TH, Yu J, Ng R, Johnson DA, Shen H, Honey CR, Johnson JA. Preferential expression of antioxidant response element mediated gene expression in astrocytes. J Neurochem. 2001; 76:1670-8. [PubMed: 11259485]

[181]. Takaya K, Suzuki T, Motohashi H, Onodera K, Satomi S, Kensler TW, Yamamoto M. Validation of the multiple sensor mechanism of the Keap1-Nrf2 system. Free Radic Biol Med. 2012; 53:817-27. [PubMed: 22732183]

[182]. Scannevin RH, Chollate S, Jung MY, Shackett M, Patel H, Bista P, Zeng W, Ryan S, Yamamoto M, Lukashev M, Rhodes KJ. Fumarates promote cytoprotection of central nervous system cells against oxidative stress via the nuclear factor (erythroid-derived 2)-like 2 pathway. $\mathrm{J}$ Pharmacol Exp Ther. 2012; 341:274-84. [PubMed: 22267202]

[183]. Metz I, Traffehn S, Strassburger-Krogias K, Keyvani K, Bergmann M, Nolte K, Weber MS, Bartsch T, Gold R, Bruck W. Glial cells express nuclear nrf2 after fumarate treatment for multiple sclerosis and psoriasis. Neurol Neuroimmunol Neuroinflamm. 2015; 2:e99. [PubMed: 25866832]

[184]. Block ML, Zecca L, Hong JS. Microglia-mediated neurotoxicity: uncovering the molecular mechanisms. Nat Rev Neurosci. 2007; 8:57-69. [PubMed: 17180163]

[185]. Rojo AI, McBean G, Cindric M, Egea J, Lopez MG, Rada P, Zarkovic N, Cuadrado A. Redox control of microglial function: molecular mechanisms and functional significance. Antioxid Redox Signal. 2014; 21:1766-801. [PubMed: 24597893]

[186]. Lawson LJ, Perry VH, Dri P, Gordon S. Heterogeneity in the distribution and morphology of microglia in the normal adult mouse brain. Neuroscience. 1990; 39:151-70. [PubMed: 2089275]

[187]. Lull ME, Block ML. Microglial activation and chronic neurodegeneration. Neurotherapeutics. 2010; 7:354-65. [PubMed: 20880500]

[188]. Block ML, Hong JS. Microglia and inflammation-mediated neurodegeneration: multiple triggers with a common mechanism. Prog Neurobiol. 2005; 76:77-98. [PubMed: 16081203]

[189]. Innamorato NG, Rojo AI, Garcia-Yague AJ, Yamamoto M, de Ceballos ML, Cuadrado A. The transcription factor Nrf2 is a therapeutic target against brain inflammation. J Immunol. 2008; 181:680-9. [PubMed: 18566435]

[190]. Wang X, de Rivero Vaccari JP, Wang H, Diaz P, German R, Marcillo AE, Keane RW. Activation of the nuclear factor E2-related factor 2/antioxidant response element pathway is neuroprotective after spinal cord injury. J Neurotrauma. 2012; 29:936-45. [PubMed: 21806470]

Free Radic Biol Med. Author manuscript; available in PMC 2016 November 01. 
[191]. Lastres-Becker I, Innamorato NG, Jaworski T, Rabano A, Kugler S, Van Leuven F, Cuadrado A. Fractalkine activates NRF2/NFE2L2 and heme oxygenase 1 to restrain tauopathy-induced microgliosis. Brain. 2014; 137:78-91. [PubMed: 24277722]

[192]. Li E, Noda M, Doi Y, Parajuli B, Kawanokuchi J, Sonobe Y, Takeuchi H, Mizuno T, Suzumura A. The neuroprotective effects of milk fat globule-EGF factor 8 against oligomeric amyloid beta toxicity. J Neuroinflammation. 2012; 9:148. [PubMed: 22742657]

[193]. LoGerfo A, Chico L, Borgia L, Petrozzi L, Rocchi A, D'Amelio A, Carlesi C, Caldarazzo Ienco E, Mancuso M, Siciliano G. Lack of association between nuclear factor erythroid-derived 2-like 2 promoter gene polymorphisms and oxidative stress biomarkers in amyotrophic lateral sclerosis patients. Oxid Med Cell Longev. 2014; 2014:432626. [PubMed: 24672634]

[194]. von Otter M, Landgren S, Nilsson S, Celojevic D, Bergstrom P, Hakansson A, Nissbrandt H, Drozdzik M, Bialecka M, Kurzawski M, Blennow K, Nilsson M, Hammarsten O, Zetterberg H. Association of Nrf2-encoding NFE2L2 haplotypes with Parkinson's disease. BMC Med Genet. 2010; 11:36. [PubMed: 20196834]

[195]. von Otter M, Bergstrom P, Quattrone A, De Marco EV, Annesi G, Soderkvist P, Wettinger SB, Drozdzik M, Bialecka M, Nissbrandt H, Klein C, Nilsson M, Hammarsten O, Nilsson S, Zetterberg H. Genetic associations of Nrf2-encoding NFE2L2 variants with Parkinson's disease a multicenter study. BMC Med Genet. 2014; 15:131. [PubMed: 25496089]

[196]. Chen YC, Wu YR, Wu YC, Lee-Chen GJ, Chen CM. Genetic analysis of NFE2L2 promoter variation in Taiwanese Parkinson's disease. Parkinsonism Relat Disord. 2013; 19:247-50. [PubMed: 23176750]

[197]. von Otter M, Landgren S, Nilsson S, Zetterberg M, Celojevic D, Bergstrom P, Minthon L, Bogdanovic N, Andreasen N, Gustafson DR, Skoog I, Wallin A, Tasa G, Blennow K, Nilsson M, Hammarsten O, Zetterberg H. Nrf2-encoding NFE2L2 haplotypes influence disease progression but not risk in Alzheimer's disease and age-related cataract. Mech Ageing Dev. 2010; 131:10510. [PubMed: 20064547]

[198]. Bergstrom P, von Otter M, Nilsson S, Nilsson AC, Nilsson M, Andersen PM, Hammarsten O, Zetterberg H. Association of NFE2L2 and KEAP1 haplotypes with amyotrophic lateral sclerosis. Amyotroph Lateral Scler Frontotemporal Degener. 2014; 15:130-7. [PubMed: 24102512]

[199]. Wang, L.; Lewis, T.; Zhang, YL.; Khodier, C.; Magesh, S.; Chen, L.; Inoyama, D.; Chen, Y.; Zhen, J.; Hu, L.; Beamer, LJ.; Faloon, PW.; Dandapani, S.; Perez, JR.; Munoz, B.; Palmer, M.; Schreiber, S. Probe Reports from the NIH Molecular Libraries Program. Bethesda (MD): 2010. The identification and characterization of non-reactive inhibitor of Keap1-Nrf2 interaction through HTS using a fluorescence polarization assay.

[200]. Williamson TP, Amirahmadi S, Joshi G, Kaludov NK, Martinov MN, Johnson DA, Johnson JA. Discovery of potent, novel Nrf2 inducers via quantum modeling, virtual screening, and in vitro experimental validation. Chem Biol Drug Des. 2012; 80:810-20. [PubMed: 22925725]

[201]. Wu KC, McDonald PR, Liu JJ, Chaguturu R, Klaassen CD. Implementation of a highthroughput screen for identifying small molecules to activate the Keap1-Nrf2-ARE pathway. PLoS One. 2012; 7:e44686. [PubMed: 23056183]

[202]. Schaap M, Hancock R, Wilderspin A, Wells G. Development of a steady-state FRET-based assay to identify inhibitors of the Keap1-Nrf2 protein-protein interaction. Protein Sci. 2013; 22:1812-9. [PubMed: 24130096]

[203]. Wang R, Mason DE, Choe KP, Lewin AS, Peters EC, Luesch H. In vitro and in vivo characterization of a tunable dual-reactivity probe of the Nrf2-ARE pathway. ACS Chem Biol. 2013; 8:1764-74. [PubMed: 23773140]

[204]. Shen T, Chen XM, Harder B, Long M, Wang XN, Lou HX, Wondrak GT, Ren DM, Zhang DD. Plant extracts of the family Lauraceae: a potential resource for chemopreventive agents that activate the nuclear factor-erythroid 2-related factor 2/antioxidant response element pathway. Planta Med. 2014; 80:426-34. [PubMed: 24585092]

[205]. van der Linden SC, von Bergh AR, van Vught-Lussenburg BM, Jonker LR, Teunis M, Krul CA, van der Burg B. Development of a panel of high-throughput reporter-gene assays to detect genotoxicity and oxidative stress. Mutat Res Genet Toxicol Environ Mutagen. 2014; 760:23-32. [PubMed: 24362253] 
[206]. Hancock R, Bertrand HC, Tsujita T, Naz S, El-Bakry A, Laoruchupong J, Hayes JD, Wells G. Peptide inhibitors of the Keap1-Nrf2 protein-protein interaction. Free Radic Biol Med. 2012; 52:444-51. [PubMed: 22107959]

[207]. Zhuang C, Miao Z, Sheng C, Zhang W. Updated Research and Applications of Small Molecule Inhibitors of Keap1-Nrf2 Protein-Protein Interaction: a Review. Curr Med Chem. 2014

[208]. de Zeeuw D, Akizawa T, Audhya P, Bakris GL, Chin M, Christ-Schmidt H, Goldsberry A, Houser M, Krauth M, Lambers Heerspink HJ, McMurray JJ, Meyer CJ, Parving HH, Remuzzi G, Toto RD, Vaziri ND, Wanner C, Wittes J, Wrolstad D, Chertow GM, Beacon Trial Investigators. Bardoxolone methyl in type 2 diabetes and stage 4 chronic kidney disease. N Engl J Med. 2013; 369:2492-503. [PubMed: 24206459]

[209]. Reisman SA, Ward KW, Klaassen CD, Meyer CJ. CDDO-9,11-dihydrotrifluoroethyl amide (CDDO-dhTFEA) induces hepatic cytoprotective genes and increases bile flow in rats. Xenobiotica. 2013; 43:571-8. [PubMed: 23244591]

[210]. Li B, Abdalrahman A, Lai Y, Janicki JS, Ward KW, Meyer CJ, Wang XL, Tang D, Cui T. Dihydro-CDDO-trifluoroethyl amide suppresses inflammatory responses in macrophages via activation of Nrf2. Biochem Biophys Res Commun. 2014; 444:555-61. [PubMed: 24486487]

[211]. Reisman SA, Lee CY, Meyer CJ, Proksch JW, Ward KW. Topical application of the synthetic triterpenoid RTA 408 activates Nrf2 and induces cytoprotective genes in rat skin. Arch Dermatol Res. 2014; 306:447-54. [PubMed: 24362512]

[212]. Probst BL, Trevino I, McCauley L, Bumeister R, Dulubova I, Wigley WC, Ferguson DA. RTA 408, A Novel Synthetic Triterpenoid with Broad Anticancer and Anti-Inflammatory Activity. PLoS One. 2015; 10:e0122942. [PubMed: 25897966]

[213]. Tobon-Velasco JC, Vazquez-Victorio G, Macias-Silva M, Cuevas E, Ali SF, Maldonado PD, Gonzalez-Trujano ME, Cuadrado A, Pedraza-Chaverri J, Santamaria A. S-allyl cysteine protects against 6-hydroxydopamine-induced neurotoxicity in the rat striatum: involvement of Nrf2 transcription factor activation and modulation of signaling kinase cascades. Free Radic Biol Med. 2012; 53:1024-40. [PubMed: 22781654]

[214]. Garcia E, Santana-Martinez R, Silva-Islas CA, Colin-Gonzalez AL, Galvan-Arzate S, Heras Y, Maldonado PD, Sotelo J, Santamaria A. S-allyl cysteine protects against MPTP-induced striatal and nigral oxidative neurotoxicity in mice: participation of Nrf2. Free Radic Res. 2014; 48:15967. [PubMed: 24147739]

[215]. Williamson TP, Johnson DA, Johnson JA. Activation of the Nrf2-ARE pathway by siRNA knockdown of Keap1 reduces oxidative stress and provides partial protection from MPTPmediated neurotoxicity. Neurotoxicology. 2012; 33:272-9. [PubMed: 22342405]

[216]. Galuppo M, Iori R, De Nicola GR, Bramanti P, Mazzon E. Anti-inflammatory and antiapoptotic effects of (RS)-glucoraphanin bioactivated with myrosinase in murine sub-acute and acute MPTP-induced Parkinson's disease. Bioorg Med Chem. 2013; 21:5532-47. [PubMed: 23810671]

[217]. Ryu J, Zhang R, Hong BH, Yang EJ, Kang KA, Choi M, Kim KC, Noh SJ, Kim HS, Lee NH, Hyun JW, Kim HS. Phloroglucinol attenuates motor functional deficits in an animal model of Parkinson's disease by enhancing Nrf2 activity. PLoS One. 2013; 8:e71178. [PubMed: 23976995]

[218]. Lou H, Jing X, Wei X, Shi H, Ren D, Zhang X. Naringenin protects against 6-OHDA-induced neurotoxicity via activation of the Nrf2/ARE signaling pathway. Neuropharmacology. 2014; 79:380-8. [PubMed: 24333330]

[219]. Wang XL, Xing GH, Hong B, Li XM, Zou Y, Zhang XJ, Dong MX. Gastrodin prevents motor deficits and oxidative stress in the MPTP mouse model of Parkinson's disease: involvement of ERK1/2-Nrf2 signaling pathway. Life Sci. 2014; 114:77-85. [PubMed: 25132361]

[220]. Woo SY, Kim JH, Moon MK, Han SH, Yeon SK, Choi JW, Jang BK, Song HJ, Kang YG, Kim JW, Lee J, Kim DJ, Hwang O, Park KD. Discovery of vinyl sulfones as a novel class of neuroprotective agents toward Parkinson's disease therapy. J Med Chem. 2014; 57:1473-87. [PubMed: 24467268]

[221]. Lee JA, Kim JH, Woo SY, Son HJ, Han SH, Jang BK, Choi JW, Kim DJ, Park KD, Hwang O. A novel compound VSC2 has anti-inflammatory and antioxidant properties in microglia and in Parkinson's disease animal model. Br J Pharmacol. 2015; 172:1087-100. [PubMed: 25297649] 
[222]. Jing X, Shi H, Zhang C, Ren M, Han M, Wei X, Zhang X, Lou H. Dimethyl fumarate attenuates 6-OHDA-induced neurotoxicity in SH-SY5Y cells and in animal model of Parkinson's disease by enhancing Nrf2 activity. Neuroscience. 2015; 286:131-40. [PubMed: 25449120]

[223]. Son HJ, Choi JH, Lee JA, Kim DJ, Shin KJ, Hwang O. Induction of NQO1 and Neuroprotection by a Novel Compound KMS04014 in Parkinson's Disease Models. J Mol Neurosci. 2015

[224]. Zhang Z, Li G, Szeto SS, Chong C, Quan Q, Huang C, Cui W, Guo B, Wang Y, Han Y, Michael Siu KW, Yuen Lee SM, Chu IK. Examining the neuroprotective effects of protocatechuic acid and chrysin on in vitro and in vivo models of Parkinson disease. Free Radic Biol Med. 2015

[225]. Zhao YF, Zhang Q, Xi JY, Li YH, Ma CG, Xiao BG. Multitarget intervention of Fasudil in the neuroprotection of dopaminergic neurons in MPTP-mouse model of Parkinson's disease. J Neurol Sci. 2015 


\section{Highlights}

- Oxidative stress in neurodegenerative diseases

- The Keap1-Nrf2-ARE pathway in the brain

- Changes in Nrf2 and Nrf2-dependent genes in diseased brain tissue

- Transgenic, viral, and chemical-mediated activation of Nrf2 in animal models

- Effect of Nrf2 activation on progression of neurodegeneration in animal models 
Table 1

Chemical activators of Nrf2 that have been tested in animal models of PD.

\begin{tabular}{lcccc}
\hline Compound & PD model & Species & Nrf2-/- & Reference \\
\hline 3H-1,2-Dithiole-3-thione & MPTP & Mouse & Yes & {$[118]$} \\
CDDO-MA & MPTP & Mouse & No & {$[164]$} \\
Sulforaphane & MPTP & Mouse & Yes & $[121])$ \\
S-Allyl cysteine & 6-OHDA & Rat & No & {$[213]$} \\
S-Allyl cysteine & MPTP & Mouse & No & {$[214]$} \\
Gly-Pro-Glu bound to L-dopa & MPTP & Mouse & No & {$[110]$} \\
siKeap1 & MPTP & Mouse & No & {$[215]$} \\
Puerarin & 6-OHDA & Rat & No & {$[115]$} \\
CDDO-EA & MPTP & Mouse & Yes & {$[122]$} \\
CDDO-TFEA & MPTP & Mouse & Yes & {$[122]$} \\
(RS)-Glucoraphanin & MPTP & Mouse & No & {$[216]$} \\
Phloroglucinol & 6-OHDA & Rat & No & {$[217]$} \\
Tetramethylpyrazine & MPP & Rat & No & {$[11]$} \\
Naringenin & 6-OHDA & Mouse & No & {$[218]$} \\
Gastrodin & MPTP & Mouse & No & {$[219]$} \\
Vinyl sulfones & MPTP & Mouse & No & {$[220]$} \\
VSC2 & MPTP & Mouse & No & {$[221]$} \\
Dimethyl fumarate & 6-OHDA & Mouse & No & {$[222]$} \\
KMS04014 & MPTP & Mouse & No & {$[223]$} \\
Protocatechuic acid + Chrysin & 6-OHDA & Mouse & No & {$[224]$} \\
Fasudil & MPTP & Mouse & No & {$[225]$} \\
\hline
\end{tabular}

Free Radic Biol Med. Author manuscript; available in PMC 2016 November 01. 